\title{
MAKALELER
}

\section{İbn Ebî Hayseme’nin (ö. 279/892) Cerh-Ta'dîl İlmindeki Yeri ve Önemi}

\begin{abstract}
Mustafa Macit KARAGÖZOĞLU*
Öz: İbn Ebî Hayseme Hadis ve İslâm Tarihi disiplinlerinin gelişiminde rol oynamışa âlimlerden biridir. Her iki ilim dalını ilgilendiren mühim eseri et-Târîhu'l-kebîr'in günümüze ancak küçük bir kısmı ulaşabilmiştir. İbn Ebî Hayseme râvilerin kimlikleri, vefat tarihleri, kardeşleri, hocaları ve talebeleri gibi konulardaki zengin birikimini eserinde yansıtmış ve sonraki ricâl literatüründe ona sıkça atıf yapılmıştır. Babası Ebû Hayseme, Yahya b. Maîn ve Ahmed b. Hanbel gibi önde gelen hadis münekkitlerinin yanında yetişen İbn Ebî Hayseme, adı geçenler başta olmak üzere kendinden önceki münekkitlerin cerh-ta'dîle dair görüșlerinin intikalinde mühim rol oynamıștır. Hocalarının derslerini dikkatle takip ederek çok sayıda râviyi ve hadisi onların gündemine getiren İbn Ebî Hayseme, müstakil olarak çok az râvinin cerh ve ta‘dîli hakkında görüş belirtmiştir.

Anahtar Kelimeler: Hadis Tenkidi, İsnad, Yahya b. Maîn, et-Târîhu'l-kebîr, Márifetü'l-ihve ve'l-ahavât

The Role of Ibn Abī Khaythama (d. 279/892) in the Criticism of Hadith Transmitters

Abstract: Ibn Abī Khaythama is one of the scholars who contributed to the development of both hadith and Islamic historiography. His most important work al-Tärīkh alKabir has only partially survived today. Ibn Abī Khaythama manifested his expertise on hadith transmitters by providing detailed information about their identification, years of death, relatives and intellectual surroundings, and was therefore quoted frequently by later authors. Having received education from prominent hadith critics, including his father Abū Khaythama, Yạ̣yā b. Ma'īn, and Aḥmad b. Hanbal, Ibn Abī Khaythama played a significant role in the transmission of their critical opinions. Though he regularly participated in hadith circles and raised questions to his teachers about transmitters and their hadiths, he rarely expressed his individual opinion regarding the impugnment and certification of the transmitters.
\end{abstract}

Keywords: Hadith Criticism, Isnād, Yahyā b. Maīin, al-Tārīkh al-Kabīr, Brothers and Sisters among Transmitters

\section{Giriş}

"İbn Ebî Hayseme” diye tanınan Ebû Bekir Ahmed b. Züheyr b. Harb (ö. 279/892) ${ }^{1}$ hadis tenkidinin III./IX. yüzyıldaki gelişimine katkı yapmış âlimlerden biridir. Döneminin önde

\footnotetext{
Yrd. Doç. Dr., Marmara Üniversitesi İlâhiyat Fakültesi Hadis Anabilim Dalı Öğretim Üyesi.

E-posta: mkaragozoglu@marmara.edu.tr

1 Hayatı hakkında aşağıda atıf yapılacak eserlere ilaveten bk. İbn Ebî Hayseme, et-Târîhu’l-kebîr, I, 15-25 ( önsözü);
} 
gelen hadisçi ve tarihçilerinden ders almış olması, hem Hadis hem İslâm Tarihi disiplinini ilgilendiren Târîh'i ve hadis râvilerine (ricâl) dair eserlerde kendisine sıkça atıf yapılması onu önemli kılan özelliklerdendir.

İbn Ebî Hayseme’nin incelenmesi günümüzün ilahiyat çalışmalarına iki yönden katkı sağlayabilir. İlk olarak İbn Ebî Hayseme, bugünkü akademik yapılanmada birbirinden kalın çizgilerle ayrılmış olan Hadis ve İslâm Tarihi ilim dalları arasında yoğun geçişkenliklerin olduğu bir zaman diliminde yaşamıştır; bu sebeple iki disiplin arasındaki mefhum, mesele, metot ve telif tarzı yönünden benzerliklerin ve farkların tespiti için elverişli bir figürdür. İkinci olarak, Yahya b. Maîn (ö. 233/848), Ali b. el-Medînî (ö. 234/848-9), Ahmed b. Hanbel (ö. 241/855) ve Ebû Züra er-Râzî (ö. 264/878) gibi meşhur hadis münekkitlerinin çok sayıda talebesi bulunmaktadır. Bu talebeler hocaları kadar meşhur olmasalar da onların meclislerinde bulunmuş; sordukları sorular, itirazlar, ilave açıklamalarla ve daha da önemlisi onların görüşlerini tedvin ederek yaygınlaştırmalarıyla hadis/râvi tenkidinin gelişimine katkıda bulunmuşlardır. Bu kişilerden biri olan İbn Ebî Hayseme’nin incelenmesi tenkit faaliyetinin tarihçesini inşaya yardımcı olma ve aynı konumdaki diğer şahsiyetlerin çalışılması için bir ön veri oluşturma potansiyeline sahiptir.

Bu makale İbn Ebî Hayseme’nin diğer alanlardan ziyade râvi tenkidindeki rolünü belirlemeyi hedeflemektedir. Bu amaçla, önce İbn Ebî Hayseme’nin, üzerinde etkili olmuş âlimler ve eserler çerçevesinde ilmî kişiliği anahatlarıyla ortaya konulacak, ardından başlıca eseri olan Târîh hakkında bilgi verilecek, son olarak ricâl tenkidindeki yeri tartışlacaktır. İbn Ebî Hayseme’nin hangi râvileri tenkit ettiği ve bu tenkitlerde kimlerin görüşlerine dayandığı gibi meseleler, onun kendi Târîh'inin yanı sıra cerh-tadîl literatürünü temsil kabiliyetine sahip eserlere başvurularak incelenecektir. Makalede İbn Ebî Hayseme’nin hocaları ile eserinin tasnif metodu ve muhtevası gibi konularda İslâm tarihçilik geleneği ile irtibat kurulmaya çalışılmışsa da, buradaki tespitler Hadis-Tarih ilişkisine dair yapılması gereken daha geniş ölçekli ve uzun soluklu araştırmalar için ancak mütevazi bir katkı olarak görülmelidir.

İbn Ebî Hayseme’nin cerh-taddîl ilmindeki yerini inceleyen Türkçe bir çalışma mevcut değildir. ${ }^{2}$ Arapça’da ise İbn Ebî Hayseme’nin ilelü’l-hadis bilgisini 56 örnek rivayet üzerinden ele alan bir yüksek lisans tezi bulunmaktadır. ${ }^{3}$ Cerh-tádîlden ziyade ilel konusuna odaklanan bu çalışma, İbn Ebî Hayseme’nin rivayetler arasındaki farklılıkları nasıl değerlendirdiğini ve ne gibi tercihler yaptığını incelemektedir. Büyük ölçüde tez yazarının ilgili rivayetler

Vüseynî, "İbn Ebî Hayseme ve Kitâbühû et-Târîh: Min hılâli nüsha hattıye 'atîka”, s. 394-402; Aydınlı, "İbn Ebû Hayseme”, DİA, XIX, 434; Gökçe, İbn Ebî Hayseme’de Sahabe Bilgisi, s. 9-14.

2 Türkçe'de İbn Ebî Hayseme üzerine yapıldığını tespit edebildiğimiz tek çalışma, künyesi kaynakçada verilen Aziz Gökçe'ye ait yüksek lisans tezidir. İbn Ebî Hayseme’nin sahâbeyi tespit metotlarını inceleyen çalışma, onun râvi tenkidindeki rolü üzerinde durmamaktadır.

3 Muhammed b. Abdullah es-Süreyyi', el-Ehâdîs elletî zekera İbn Ebî Hayseme fîhâ ihtilâfen fî et-Târîhi'l-kebîr (yüksek lisans tezi), Kasîm (Suudi Arabistan) 2014. Yazar, tezinde ulaştığı sonuçları şu yazıda özetlemiştir: http://www.alukah. net/sharia/0/104544/ (erişim tarihi: 24.02.2017). 
hakkındaki uzun analizlerinden oluşan eser, İbn Ebî Hayseme’nin ricâl tenkidindeki yerini belirginleştirmek için tek başına yeterli gözükmemektedir.

\section{Hadisçilik ve Tarihçilik Gelenekleriyle İrtibatı Çerçevesinde İbn Ebî Hayseme'nin İlmî Şahsiyeti}

Yaygın kanaate göre İbn Ebî Hayseme 185-279/801-892 yılları arasında yaşamıştır. ${ }^{4}$ Ömrünün çok büyük kısmını Bağdat'ta geçiren İbn Ebî Hayseme’nin Târîh'indeki kayıtlar onun en azından iki şehre, yani Basra ve Mekke’ye gittiğini göstermektedir. O, ilgili rivayetten anlaşıldığı kadarıyla yanında babası olmaksızın hicrî 219 yılında Mekke’ye gitmek üzere yola çı kmış, ${ }^{5} 220$ senesinde ise İbn Maîn'le birlikte Basra’da bulunmuştur. ${ }^{6}$ İbn Ebî Hayseme’nin Bağdat’tan çıktığına dair başka bir bilgi olmasa da dönemin ilmî gelenekleri gereği başka yerlere de seyahat etmiş olması muhtemeldir.

Hocaları arasında babası Ebû Hayseme Züheyr b. Harb (ö. 234/849), Yahya b. Maîn, Ahmed b. Hanbel, Ebû Seleme Musa b. İsmail et-Tebûzekî (ö. 223/838), Affân b. Müslim (ö. 220/835) ve Süleyman b. Harb (ö. 224/839) gibi tanınmış muhaddisler bulunur. Ondan ders alan talebelerden bazıları ise oğlu Ebû Abdullah Muhammed b. Ebû Bekir (ö. 297/910), ${ }^{7}$ Târîh'in de râvilerinden olan Ebü'l-Kasım el-Begavî (ö. 317/929), Yahya b. Muhammed b. Sâid (ö. 318/930), Hüseyin b. İsmail el-Mehâmilî (ö. 330/942), Kasım b. Asbağ (ö. 340/951) ve İsmail b. Muhammed es-Saffâr'dır (ö. 341/952-3). Hadis münekkitleri, İbn Ebî Hayseme’nin güvenilir bir muhaddis olduğunu kaydetmişlerdir. ${ }^{8}$

Hatîb el-Bağdâdînin (ö. 463/1071), İbn Ebî Hayseme’nin bilgi kaynakları hakkındaki şu ifadeleri son derece özlü olup sonraki müelliflerce sıkça iktibas edilmiştir: "Hadis ilmini Yahya b. Maîn ve Ahmed b. Hanbel'den, neseb ilmini Mus'ab b. Abdullah ez-Zübeyrî̀den [ö. 236/851], savaşları ve diğer tarihî olayları (eyyâmü’n-nâs) Ebü’l-Hasan el-Medâinîden [ö. 228/843], edebiyatı Muhammed b. Sellâm el-Cumahîden [ö. 231/846] öğrendi.” 9

“el-Hâfız" ve "el-ahbârî” unvanlarıyla anılması, İbn Ebî Hayseme’nin ilmî kişiliğinin öne çıkan iki yönüne işaret eder: Hadisçilik ve tarihçilik. ${ }^{10}$ İbn Ebî Hayseme’nin hocaları ile

4 Hatîb el-Bağdâdî, Târîh, V, 267; İbn Ebî Ya'lâ, Tabakâtü’l-Hanâbile, I, 98. Zehebî daha geç bir tarihte doğmuş olması gerektiğini söylerken İbn Hacer 205-297/820-910 yılları arasında yaşadığını nakletmiş ancak İbn Hacer'in özellikle vefat yılına dair görüşü isabetli bulunmamıştır (Zehebî, Siyer, XI, 493; İbn Hacer, Lisân, I, 463-464 [dp. 1 ile birlikte]).

5

6

İbn Ebî Hayseme, Târîh, I, 201-202 (prg. 537). Onun Basra’da bulunduğunu tarih vermeksizin belirten bir diğer ifade için bk. Târîh, III, 255-256.

7 Târîh'in telifinde babasına yardımcı olduğu kaydedilmiștir (Zehebî, Siyer, XI, 494).

8 İbn Ebî Hâtim, el-Cerh ve’t-tádîl, II, 52; Hatîb, Târîh, V, 265-266. Onun Kaderiyye’den olduğuna dair haber muhtemelen hata mahsulü olup başka kaynaklarca desteklenmez (İbn Hacer, Lisân, I, 464 [dp. 1 ile birlikte]).

9 Hatîb, Târîh, V, 266.

10 İbnü’n-Nedîm, İbn Ebî Hayseme için ayırdığı kısa paragrafta onun muhaddis-ahbârîlerden olduğunu belirtir, ayrıca fakih kimliğinin de bulunduğunu söyler (... من المحدثين الاخباريين وكان فقيها) (el-Fihrist, s. 321). 
irtibatına, dönemindeki yaygın ilim gelenekleri eşliğinde biraz daha yakından bakarak onun hakkında daha belirgin bir resme ulaşabiliriz.

Hatîb'in, İbn Ebî Hayseme’nin hadisteki başlıca hocaları olarak belirlediği Yahya b. Maîn ve Ahmed b. Hanbel, hadis tenkidinin III./IX. yüzyılın başlarındaki tartışmasız en etkili isimlerindendir. Yahya b. Maîn hadis râvilerini incelemeye adadığı ömrüyle cerh-tađîl alanında klasik dönemdeki muhaddislerin birinci başvuru kaynağ ${ }_{1}$ olmuş, ${ }^{11}$ İbn Hanbel ise ricâl ve ilel bilgisinin yanı sıra fıkhî ve itikâdî görüşleriyle Ehl-i hadîs’in en meşhur siması haline gelmiştir. İbn Ebî Hayseme, babasının onlarla arkadaşlı̆̆ından da istifadeyle bu iki isme talebelik yapmış, bazı seyahatlerinde yanlarında bulunmuş, râviler hakkında sorular sormuş, aldığı cevapları ve diğer duyduklarını Târîh’teki sayısız rivayette görüldüğü gibi özenle kaydetmiş, böylece bu iki âlimin ilmî birikimini başka râvilerle birlikte sonraki nesillere intikal ettirmiştir.

İbn Ebî Hayseme’nin ilmî kişiliğinin şekillenmesinde etkili olmuş bir diğer hocası, babası Ebû Hayseme Züheyr b. Harb'dir. ${ }^{12}$ İlme dair hadislerden oluşan Kitâbü'l-İlm’i ile tanınan Ebû Hayseme, 160/776 yılında Nesâda doğdu, ömrünün ilerleyen safhalarında Bağdat’a yerleşti. Vekî‘ b. el-Cerrâh (ö. 197/812), Süfyan b. Uyeyne (ö. 198/814), Yahya b. Saîd el-Kattân (ö. 198/813) gibi hocalardan hadis aldı, Tirmizî dışındaki Kütüb-i sitte müelliflerine de hocalık yaptı. Ebû Hayseme, özellikle el-Câmi'u's-sahîh'te 1281 rivayet ${ }^{13}$ ile Müslim’in (ö. 261/875) İbn Ebî Şeybe’den (ö. 235/849) sonra en çok hadis aldığı hocası konumundadır. O yalnızca güvenilir bir râvi olarak değil, arkadaşlık yaptığı Yahya b. Maîn ve Ahmed b. Hanbel gibi cerh-tadîl ve ilelü’l-hadis sahalarında görüşlerine itibar edilen bir hadis uzmanı olarak da öne çıkmıştır. Ebû Davud, Ebû Hayseme’nin ricâl konusunda hüccet olup olmadığını soran talebesi Âcurrîye, "onun ilmi ne güzeldir" cevabını vererek râvilerle ilgili kanaatlerine güvenilebileceğini vurgulamıştır. ${ }^{14}$ İbn Hanbel ve İbn Maîn'den üstün görülmese de onlarla mukayese edilmesi bile Ebû Hayseme’nin ilmî mevkii hakkında fikir vericidir. ${ }^{15}$

İbn Ebî Hayseme, döneminin bir diğer hadis üstâdı olan Ali b. el-Medînîden de istifade etmiştir. İbnü’l-Medînîden "haddesenâ" sîgasıyla naklettiği az sayıdaki rivayete ilâveten, ${ }^{16}$ ona ait birtakım yazılı malzemelerden de nakilde bulunmuştur. Zira İbnü’l-Medînînin oğlu Abdullah, babasına ait yazılı bir kitabı İbn Ebî Hayseme’ye vermiştir. ${ }^{17}$ Bu kitapta İbnüll-Medînînin Yahya b. Saîd el-Kattân gibi hocalarından naklettiği muhtelif ricâl değerlendirmeleri bulunmaktadır. İbn Ebî Hayseme, "bu kitapta [Târîh] (قال علي) diyerek naklettiğim şeyler

11 İbn Maîn’in bu konumu için bk. Karagözoğlu, Zayıf Râvîler, s. 128 vd.

12 Hayatı hakkında bk. Hatîb, Târîh, IX, 509-511; Zehebî, Siyer, XI, 489-492; Tuğ, Ebû Hayseme, s. 1-17.

13 İbn Hacer, Tehzîbü't-Tehzîb, I, 637.

14 Hatîb, Târîh, IX, 510.

15 İbn Ebî Hâtim, el-Cerh ve’t-ta'dîl, II, 69.

16 İbn Ebî Hayseme, Târîh, I, 227 (prg. 691), 290 (prg. 1021), 293 (prg. 1036).

17 İbn Ebî Hayseme, Târîh, I, 201-202 (prg. 537) [Yazılı metni bizzat İbnü’l-Medînînin verdiğini çă̆rıştıran ana metindeki ibarenin hatalı olduğu, muhakkike ait dp. l'de açıklanmıştır]. Kitabı verenin İbnü’l-Medînînin oğlu olduğunu gösteren bir diğer ifade için bk. a.g.e., II, 109 (prg. 1968). 
bizzat Aliden duymayıp bu kitaptan yazdıklarımdır” demiştir. ${ }^{18}$ O, sözkonusu kitaba (فأيت diyerek de atıf yapmıştır. ${ }^{19}$

İbn Ebî Hayseme’nin irtibat kurduğu ilmî geleneklerden ilki Yahya el-Kattân, Abdurrahman b. Mehdî (ö. 198/814), Vekî‘ neslinden sonra hadis tenkidini daha kapsamlı ve sistematik bir çehreye büründüren Yahya b. Maîn, Ahmed b. Hanbel ve Ali b. el-Medînî gibi isimlerce temsil edilen hadisçiliktir. İkinci olarak, İbn Ebî Hayseme’nin güçlü bir tarihçilik nosyonuna sahip olduğu görülmektedir. Onun bu alanda istifade ettiği hocaları arasındaki Muśab b. Abdullah ez-Zübeyrî, meşhur sahâbî Abdullah b. ez-Zübeyr’in (ö. 73/692) neslinden gelmekte olup Medine'de doğduktan sonra hayatının ilerleyen safhalarında Bağdat'a giderek vefatına kadar orada yaşamıştır. Muśab ez-Zübeyrî genel mânâda neseb, özel olarak da Kureyş'in nesebi konusunda sonraki tarihçiler tarafından üstad kabul edilmiş, bu sahadaki uzmanlığı Yahya b. Maîn tarafından da teslim edilmiştir. ${ }^{20}$ Eserinde Kureyş kabilelerinin Hz. Âdem’e kadar soy bağlarını tespit eden Zübeyrî yalnızca neseb değil eyyâmü’l-Arab konusunda da bilgiliydi. İbn Ebî Hayseme, Zübeyrînin en seçkin talebesiydi ve onun Nesebü Kureyş isimli kitabını rivayet etmişti.

İbn Ebî Hayseme’nin diğer tarihçi hocası Ebü'l-Hasan Ali b. Muhammed b. Abdullah el-Medâinî, 135/752'de Basra'da doğduktan sonra, nisbesini aldığı Medâin'e ve Bağdat'a gitti. ${ }^{21}$ Hocaları arasında Ebû Mihnef (ö. 157/773-4), Hammâd b. Seleme (ö. 167/784), Mu'tezile kelamcısı Muammer b. Abbâd es-Sülemî (ö. 215/830) ve İshak b. İbrahim el-Mevsılî (ö. 235/850) gibi isimler yer almaktadır. Arap tarihini rivayetler ekseninde ve hadisçilerin hassasiyetlerini gözeterek işlemesi, Medâinîye ilk dönem İslâm tarihçileri arasında seçkin bir mevki kazandırmıştır. Muhtemelen bu yüzden Zehebî onu, "siyer, megâzî, ensâb ve eyyâmü'l-Arab konularında muazzam birisiydi, naklettikleri başkalarınca doğrulanırdı ve âlî isnadlara sahipti” 22 diye nitelemiştir. Medâinî, "Ebû Mihnef, Avâne b. Hakem [ö. 147/764], Seyf b. Ömer [ö. 180/796] gibi şahsiyetlerin oluşturduğu ahbârîler çizgisinin en büyük halkasını teşkil etmiştir." 23 İrili ufaklı yazdığı çok sayıda eserinde sunduğu bilgiler, İslâm Tarihine dair yazılmış sonraki hacimli eserlerin içerisinde yer almıştır.

Medâinî ile bizzat görüşen İbn Ebî Hayseme, onun Halîfe b. Hayyât (ö. 240/854-5) ve Zübeyr b. Bekkâr (ö. 256/870) gibi önde gelen talebelerinden birisidir. İbn Ebî Hayseme’nin

18 İbn Ebî Hayseme, Târîh, I, 201-202. İbn Ebî Hayseme’nin Ali b. el-Medînîden yaptığı sözkonusu nakiller hakkında ayrıca bk. Turhan, Ricâl Tenkidinin Doğuşu ve Gelişimi, s. 353-354.

19 İbn Ebî Hayseme, Târîh, II, 166 (prg. 2242), 170 (prg. 2263), 196 (prg. 2376), 213 (prg. 2505), 217 (prg. 2525 ), 228 (prg. 2597), 233 (prg. 2631), 240 (prg. 2672), 253 (prg. 2748); III, 223 (prg. 4549), 224 (prg. 4561 ), 267 (prg. 4785 ).

20 Zübeyrî̀nin hayatı ve ilmî şahsiyeti hakkında bk. Zübeyrî, Nesebü Kureyş, s. 5-9, 14-17 (neşredenin önsözü); İbnü’nNedîm, el-Fihrist, s. 160; Hatîb, Târîh, XV, 138-141; Uyar, "Abbâsî Coğrafyasında Bir Neseb Âlimi: Zübeyrî (236/851)", s. $127-152$.

21 Hayatı hakkında bk. Zehebî, Siyer, X, 400-402; İbn Hacer, Lisân, VI, 13-14; Sezgin, "Al-Madāinī”, EI', V, 946-8; Kallek, "Medâinî", DİA, XXVIII, 291-292.

22 Zehebî, Siyer, X, 400-401.

23 Kallek, "Medâinî", DİA, XXVIII, 291. 
Târîh'inde Medâinî̀ye genellikle şahıs maddelerinin sonunda, vefat yerleri ve tarihleri türünden bilgiler verilirken atıf yapılmıştır. Ayrıca ondan şahısların kimliklerinin ve nisbelerinin tespitine dair bilgiler de nakledilmiştir. Hicrî 210 yılına kadar Medine’ye kadı veya yönetici olarak atananların isim isim sıralandığı uzun bir liste de Medâinîden gelmiştir. ${ }^{24}$ Medâinîye yapılan atıfların çoğunda bilgi ondan nakledilmekte, hicrî takvimin başlangıcı hakkındaki haberde olduğu gibi bir kısmında ise isnadlı olarak önceki şahsiyetlere uzanmaktadır. ${ }^{25}$

İbn Ebî Hayseme’nin anlattığı ve içerisinde Muśab ez-Zübeyrî ile Medâinînnin de geçtiği şu hâdise birçok açıdan dikkate değerdir:

Babam, Muśab ez-Zübeyrî ve Yahya b. Maîn akşamları Musáa'ın kapısında otururlardı. Bir gece, gösterişli bir merkebin üstünde, güzel kıyafetli bir adam geldi, selam verdikten sonra Yahya b. Maîn'le kendi aralarında biraz konuştular. Yahya ona, “Ebü'l-Hasan! Nereye gidiyorsun?” diye sordu. O, "Elbisemin kollarını dinar ve dirhemle dolduran şu cömert insana, İshak b. İbrahim el-Mevsılîye gidiyorum” dedi. Adam arkasını dönüp gidince Yahya üç kere "Sika” dedi. Babama "Bu kimdi?" diye sordum, "Medâinî" diye cevap verdi. ${ }^{26}$

Burada ilk olarak, İbn Ebî Hayseme’nin babası Züheyr b. Harb’in Mus'ab ez-Zübeyrî ve İbn Maîn ile akşamları muhtemelen ilmî müzakere yapmak üzere bir araya geldikleri ve İbn Ebî Hayseme’nin de bu sohbetlere şahit olduğu görülmektedir. İkinci olarak, henüz birbirinden bütünüyle ayrılmamış olan hadisçilik ve tarihçilik geleneklerini temsil eden kişiler arasındaki yakın ilişkiye işaret bulunmakta ve Zübeyrî ile Medâinînin her iki sahanın da hassasiyetlerine cevap verebildiği anlaşılmaktadır. Bu pasaj son olarak İbn Ebî Hayseme’nin her iki ilim geleneğini beraberce nasıl tevârüs edebildiğine ışık tutmaktadır.

İbn Ebî Hayseme’nin tarihçilik geleneğiyle irtibatı Zübeyrî ve Medâinî kanallarıyla sınırlı değildir. O, tâbiûn tabakasındaki ilk siyer-megâzî müelliflerinden Urve b. ez-Zübeyr (ö. 94/713) ve İbn Şihâb ez-Zührîđden (ö. 124/742) gelen pek çok rivayete yer vermiştir. ${ }^{27}$ İbn Şihâb’dan İbn Ebî Hayseme’ye uzanan tarikler arasında (İbn Şihâb $\rightarrow$ Musa b. Ukbe $\rightarrow$

24 İbn Ebî Hayseme, Târîh, II, 61-69.

25 İbn Sîrîn kaynaklı bu haber için bk. İbn Ebî Hayseme, Târîh, I, 365-366.

26 Zehebî, Siyer, X, 401. Yahya b. Maîn gibi titiz bir münekkidin böylesine mübalağalı biçimde ta‘dîl ettiği Medâinî hakkında İbn Adî (ö. 365/976) "hadiste kuvvetli değildir, tarihe dair çok sayıda rivayete sahiptir (ومويس بالقوي في الحديث)" (وهو صاحب الاخبار "demiştir (el-Kâmil, VIII, 189). Hadisçilikle tarihçiliğin üçüncü yüzyılın ilk çeyreğine kıyasla çok daha keskin şekilde ayrıştığı bir dönemde yazan İbn Adî, ilgili biyografinin genelinde hissedildiği üzere, Medâinînin hadis dışı iştigallerini vurgulayarak "müsned" hadislerinin sayısının az olduğunu belirtmiştir. Zehebî ise el-Muğnîde İbn Adînin görüşüne yer vermesine rağmen Medâinîyi "sadûk” diye niteleyerek genel mânâda güvenilir bulmuş (II, 23), başka bir eserinde de İbn Adînin görüşünün hemen arkasından Yahya b. Maîn'in tevsikini naklederek kanaatini hissettirmiştir (Mîzân, V, 185). Bu görüş farklılığı Medâinînin az sayıdaki müsned rivayetiyle ilgili olup onun genel mânâda hadisçilere yakın duran ilim anlayışını etkileyecek boyutta değildir.

27 Târîh'te kendilerine atıf yapılan yerleri topluca görmek için bk. İbn Ebî Hayseme, Târîh, IV, 262-263, 355-356, 365366. 
Muhammed b. Fuleyh $\rightarrow$ İbrahim b. el-Münzir $\rightarrow$ İbn Ebî Hayseme) öne çıkar. ${ }^{28}$ Buradaki Musa b. Ukbe'nin (ö. 141/758) Zührî̀den de istifadeyle oluşturduğu megâzîye dair eseri, Mâlik başta olmak üzere muhaddisler tarafından en sahih görülen siyer kitaplarından biridir. Musa b. Ukbe ile aynı dönemde siyer çalışmalarını biraz daha sistematik hale büründürmüş olan İbn İshak’ın (ö. 151/768) es-Sîre’si de İbn Ebî Hayseme tarafindan yoğun olarak kullanılmıştır. İbn Ebî Hayseme, es-Sîre'ye başka birtakım hocalarının yanı sıra (İbn İshâk $\rightarrow$ Ebû İshâk İbrahim b. Sa‘d $\rightarrow$ Ahmed b. Muhammed b. Eyyûb el-Bağdâdî $\rightarrow$ İbn Ebî Hayseme) tarîkiyle ulaşmış, bu yolla aldığı bilgileri genellikle "kâle İbn İshâk" diyerek Târîh’inde nakletmiştir. ${ }^{29}$

İslâm tarihçiliği bilhassa başlangıç safhalarında Hadis ilmiyle çok yakın irtibatlı olmuş, ancak zaman içinde kaynak, metot ve muhteva gibi yönlerden bağımsız bir disipline dönüşmüştür. ${ }^{30}$ Muhaddislerin ilgileri dinî içerikli ve giderek artan oranda merfû rivayetler üzerine yoğunlaşıp titiz bir isnad kullanımı etrafında şekillenirken, tarihçiler dinî sahayla sınırlı kalmayıp her türlü haberi incelemişler, vâkıaların bütüncül anlatımlarını sunmak üzere telfîk (farklı hadisleri tek bir rivayette birleştirme) uygulamasından kaçınmamışlardır. İbn Ebî Hayseme’nin yaşadığı hicrî üçüncü yüzyıl, hadisçilikle tarihçilik arasındaki ayrışma sürecinin devam ettiği, buna mukabil pek çok ortak ilgi ve hassasiyetin de korunduğu bir dönemdir. Hocalarından hem tarihçilik (ahbârîlik) hem de hadisçilik geleneklerini tevârüs eden İbn Ebî Hayseme, her iki ilim dalı için de önem taşıyan Târîh’ini ortaya koymuştur.

\section{2. et-Târîhu'l-kebîr: Tasnifi, Muhtevası ve İntikali}

İbn Ebî Hayseme’nin başka bazı eserler de yazdığı kaydedilmekteyse de, ${ }^{31}$ yaygın biçimde tanınan ve günümüzdeki varlığı bilinen eseri et-Târîhu'l-kebîr'dir. ${ }^{32}$ Toplam 50 cüzden oluştuğu belirtilen bu eserin de maalesef tamamı değil, 5-9. cüzleri ile son iki cüzünden kısımlar günümüze ulaşmış ve neşredilmiştir. ${ }^{33}$ Bütünüyle neşredilse 25-30 cildi bulması

28 Meselâ bk. İbn Ebî Hayseme, Târîh, I, 365 (prg. 1374); II, 16 (prg. 1513), 23 (prg. 1544), 38 (prg. 1597), 42 (prg. 1611), 43 (prg. 1616), 77 (prg. 1803), 113 (prg. 1982); III, 5 (3582), 7-8 (prg. 3599). İbn Ebî Hayseme’nin Zührî̀den sahâbeye dair bilgiler naklederken kullandığı isnadlar için bk. Yazıc1, Sahâbe Bilgisinin Tespiti, s. 231-232.

29 İbn Ebî Hayseme’nin kendi ifadesi için bk. Târîh, II, 39. Mezkûr isnadla gelen bazı nakiller için bk. a.g.e., I, 154 (prg. 340), 367 (prg. 1380); II, 8 (prg. 1490, 1492, 1493), 10 (prg. 1497), 15 (prg. 1510), 29 (prg. 1563).

30 İslâm tarihçiliğinin erken dönemdeki gelişimini hadisle irtibatlı olarak ele alan çalışmaların bazıları şunlardır: Rosenthal, A History of Muslim Historiography, s. 18-105; Hizmetli, İslâm Tarihçiliği Üzerine; Khalidi, Arabic Historical Thought in the Classical Period, s. 1-82; Horovitz, The Earliest Biographies of the Prophet and Their Authors, Darwin Press, Princeton 2002 (trc. İslâmî Tarihçiliğin Doğuşu: İlk Siyer/Meğazi Eserleri ve Müellifleri); Robinson, Islamic Historiography, s. 3-102; Dûrî, Neş'etü ilmi't-tarih inde'l-Arab.

31 Ona nispet edilen eserleri görmek için bk. Gökçe, İbn Ebî Hayseme’de Sahabe Bilgisi, s. 14-15.

32 Bu makalede eserin Salâh b. Fethî Helel neşri esas alınmıştır. Târîh'in bu neşirde yer almayan Kûfeli 47 râviyi içeren küçük bir kısmı Târîhu İbn Ebî Hayseme: Kıt'atün mine'l-kûfiyyîn adıyla yayımlanmıştır; bu yayın da gözden geçirilmiş fakat ilk neşrin buradaki tahlil için yeterli olduğu düşünülerek makalede ona atıf yapılmamıştır.

33 Cüzler hakkında bilgi ve bunların kitap içinde başlayıp bittiği yerler için bk. İbn Ebî Hayseme, Târîh, I, 61-62 (neşredenin önsözü). İbn Hayr ise eserin 30 cüz olduğunu kaydetmiştir (Fihrist, s. 258). 
muhtemel bu hacimli kitabın kaybı üzüntü verici olduğu kadar II-III./VIII-IX. yüzyıllara dair hadis ve tarih araştırmaları için de ciddi bir eksiklik kaynağıdır. Fakat Târîh'in bugün matbû durumda bulunan kısımları yine de bazı tespit ve çıkarımlara imkan vermekte olup titiz biçimde incelenmeyi hak etmektedir.

Târîh, eseri İbn Ebî Hayseme'den dinleyen Kâsım b. Asbağ (ö. 340/951) tarafından Mağrib’de rivayet edilmiştir. ${ }^{34}$ Hemen her Endülüslü gibi ilk eğitimini aldıktan sonra Doğu’ya ilmî seyahate çıkan Kâsım b. Asbağ, Bağdat'ta İbn Ebî Hayseme’den Târîh'i dinlemiş ve memleketine geri döndükten sonra eserin Endülüs’te yaygınlaşmasını sağlamıştır. ${ }^{35}$ Kâsım’ın en güvenilir talebesi Ebü’l-Kâsım Abdülvâris b. Süfyan (ö. 395/1005) ${ }^{36}$ Târîh'i meşhur muhaddis İbn Abdülbere (ö. 463/1071) ve "İbnü’l-Hazzâ" diye bilinen Ebû Ömer Ahmed b. Muhammed b. Yahya'ya (ö. 467/1074) ${ }^{37}$ nakletmiş, İbn Abdülber bu tariki zikrederek muhtelif eserlerinde Târîh'ten iktibaslarda bulunmuştur.

Târîh Endülüs'te yukarıdaki silsile vasıtasıyla nakledilirken doğu İslâm coğrafyasının III./IX. yüzyıldaki başlıca ilmî muhiti olan Bağdat'ta Ebû Abdullah Muhammed b. el-Hüseyin b. Muhammed ez-Záferânî (ö. 337/949) ${ }^{38}$ tarafından farklı talebelere rivayet ediliyordu. Hatîb el-Bağdâdî ve İbn Asâkir (ö. 571/1176) gibi tarihçilerin İbn Ebî Hayseme’nin eserinden iktibas ettiği pasajların büyük bölümü Záferânînin bulunduğu isnadlarla kendilerine ulaşmıştı. Aşağıda belirtileceği üzere, sonraki tarihçilerin İbn Ebî Hayseme’den yaptıkları nakillerin bir kısmı, Târîh'in günümüze ulaşamamış bölümlerini içermektedir.

Elimizdeki matbû hali çerçevesinde Târîh'in tertibi hakkında bazı tespitler yapmak mümkündür. Birden fazla tasnif düzeyine sahip olduğu anlaşılan Târîh'in bölümleri ilk olarak şehirlere ve coğrafî bölgelere göre belirlenmiştir. Mekke, Tâif, Yemen, Yemâme, Medine, Kûfe, Bizans imparatorluğuna komşu sınır bölgeleri (es-süğûr ve'l-avâsım) ve Kuzey Afrika (İfrîkiyye) kitapta geçen bölümlerdir. Her bölümde ilk olarak şehrin fazileti hakkındaki rivayetler zikredilmiş, ardından oradaki ilim adamları sahâbeden başlamak üzere tabaka tabaka ele alınmıştır. Dolayısıyla coğrafî tasnifin altında, tabaka esaslı tarihî bir yaklaşım benimsenmiştir. Ayrıca Mekke’ye ayrılan bölümün baş tarafında Resûl-i Ekrem’in hicret öncesi hayatına dair rivayetler nakledilmiş, Medine’nin faziletinden bahseden haberlerin ardından ise siyer-i Nebînnin hicret sonrasındaki kısmı anlatılmıştır. Bu sebeple kitabın Mekke ve Medine dönemi diye ikiye ayrılan muhtasar bir siyer çalışmasını içerdiği söylenebilir.

İbn Ebî Hayseme’nin Târîh'i, tasnifinde șehir ve coğrafî bölge ile tabaka kriterinin beraberce kullanılması açısından III./IX. yüzyılda yazılmış tarih ve tabakât eserleriyle benzerlik

34 Târîh'in kitap olarak rivayetine dair aşağıdaki bilgiler şuradan derlenmiştir: İbn Ebî Hayseme, Târîh, I, 42-48 (neşredenin önsözü). Konu hakkında ayrıca bk. Vüseynî, "İbn Ebî Hayseme”, s. 411-421.

36 Zehebî, Siyer, XVII, 84-85.

37 Zehebî, Siyer, XVIII, 344-346. Kâsım b. Asbağ’dan Târîh'i nakleden başka râviler de bulunmaktadır (bk. İbn Hayr, Fihrist, s. 258).

38 Záferânî hakkında bk. Hatîb, Târîh, III, 31-32. 
gösterir. Meselâ ayrıntıda küçük farklar bulunmakla birlikte, İbn Sa‘d da Tabakât’ın tertibinde şehir ile tabaka unsurunu aynı anda dikkate almıştır. ${ }^{39}$ Halîfe b. Hayyât ise Tabakât'1nın tertibinde şehir, kabile ve tabaka unsurlarını birlikte gözetmiştir. Bu eserde "Hz. Peygamber'in ashâbından Kûfe’ye yerleşenlerin isimleri (عسمية من نزل الكوفة من أصحاب رسول الله صلى الله (عليه "şeklindeki başlıklar İbn Ebî Hayseme’nin eserindekilerle hemen hemen aynıdır. ${ }^{40}$ Dolayısıyla İbn Ebî Hayseme yeni bir tasnif usûlü icat etmemiş, ana çerçevesi kendinden önce oluşturulmuş olan bir tarzı takip etmiştir.

Târîh'in tasnifi, belirli bir konunun yalnızca ilgili başlık altında ele alındığı günümüz telif mantığından kuşkusuz farklıdır. Belli bir akış ve konu üzerinde ilerlerken yazarın alâkalı gördügü başka bir meseleye geçilmesi, ardından ilk konuya tekrar dönülerek devam edilmesi, dönemin diğer tarih kitaplarında olduğu gibi İbn Ebî Hayseme’nin Târîh'inde de sıkça rastlanan bir durumdur. ${ }^{41}$ Meselâ Mücâhid b. Cebr'den (ö. 103/721) bahseden bölümde bir yerde Mücâhid'in İsrâ Sûresi'nin 79. ayeti hakkındaki tefsiri verilmiş, ardından Mücâhid'le ilgili diğer haberlere geçmeden önce aynı ayetle ilgili başka görüşler sıralanmıştır. ${ }^{42} \mathrm{Oku}$ yucu bu kısa bölümde adeta rivayet tefsirlerinden pasajlar okuduğu hissine kapılmaktadır. Saîd b. el-Müseyyeb’e (ö. 93/712) ayrılan bölümde ise fikıh ilminin tâbiûn tabakasında mevâlîye intikal ettiğini belirten bir haber nakledildikten sonra, haberde zikredilen fakih tâbiîlerin mevlâlık ilişkilerini gösteren rivayetlere yer verilmiştir. ${ }^{43}$ Yaklaşık beş sayfa süren bölümün ardından yazar Saîd b. el-Müseyyeb’le ilgili nakillere devam etmiştir. Bir diğer örnekte yazar, Esved b. Yezid'in (ö. 75/694) talebeleri arasında Âmir eş-Şa ‘bînnin (ö. 103/721) bulunduğunu göstermek üzere naklettiği rivayetin isnadında geçen râvilerin güvenilirliklerine dair dört alıntıyı peşpeşe sıralamıştır. ${ }^{44}$

Târîh'in muhtevası tek bir ilim dalıyla sınırlandırılamayacak kadar geniştir. İlk olarak şehir ve ulemâ tarihi, siyer ve hadis gibi alanlarla irtibatlandırılabilecek eser tefsire ve fikha dair rivayetler de içermektedir. Yazar, kitabının geniş ancak hadis ağırlıklı muhtevasını şu ifadelerle anlatmıştır:

Bu eseri edinen, ilmimin özünü almış olur. Onu bir ev dolusu kaynak eserden vücuda getirdim. Onda 60.000 rivayet bulunur. Bunlardan 10.000’i Hz. Peygambere kadar varan müsned hadistir. Geri kalanı ise isnadlarında kopukluk bulunan haberler ve anlatımlardır. Kitabım hadise doymuş (hadislerin çoğunu zaten kaydetmiş) kimseler içindir, o yüzden hadislerin yalnızca etrâfını (baş taraflarını) yazdım. ${ }^{45}$

39 Tabakât' in tasnifi hakkında bk. Fayda, "İbn Sa'd”, DİA, XX, 295-296.

40 Krş. Halîfe b. Hayyât, et-Tabakât, I, 280 vd; İbn Ebî Hayseme, Târîh, III, 5.

41 İbn Ebî Hayseme’nin çağdaşı olan Fesevînin (ö. 277/890) yazdı̆̆ı el-Márife ve’t-tarih'in tertibinin karmaşıklı̆̆ hakkında bir değerlendirme için bk. Âşıkutlu, Fesevî ve Ricâl İlmindeki Yeri, s. 66-69.

42 İbn Ebî Hayseme, Târîh, I, 203-205 (prg. 539 vd.).

43 İbn Ebî Hayseme, Târîh, II, 104-109 (prg. 1943 vd.).

44 İbn Ebî Hayseme, Târîh, III, 72-3 (prg. 3877).

45 İbnü'l-Ebbâr, el-Mu'cem, s. 50. Esas alınan nüshada geçen (خشى) fiilinin ilk harfi hatalı olup doğrusunun başka neşirlerde geçtiği gibi noktasız (حشى) olması gerekmektedir. 
Bu makalenin kalan kısmında İbn Ebî Hayseme’nin hadis râvileri hakkında sunduğu bilgiler merkeze alınarak onun ricâl ilmindeki yeri gösterilecek, bilhassa hadis/râvi tenkidinde rol oynayıp oynamadığı üzerinde durulacaktır. Bu yapılırken onun kendi Târîh'inin yanı sıra ricâl literatüründen seçilmiş sonraki eserlere de sıkça başvurulacaktır. ${ }^{46}$

\section{3. İbn Ebî Hayseme’nin Ricâl Tenkidindeki Rolü ve Yahya b. Maîn'le İrtibatı}

İbn Ebî Hayseme’nin, ele aldığ şahıslar hakkında verdiği rivayetler onun geniş ricâl bilgisine işaret eder. Ancak o, râvi tenkidinde tam olarak hangi rolü oynamıştır? Bizzat değerlendirdiği râvi sayısı ne kadardır? Müstakil bir münekkit sayılması mümkün müdür? Görüşlerine atıf yaptığı münekkitler arasında öne çıkanlar kimlerdir? İbn Ebî Hayseme’den gelen rivayetlere sonraki ricâl literatüründe ne oranda yer verilmiştir? Bu ve benzeri sorulara aşağıda önce Târîh'in kendisine bakılarak cevap aranacak, ardından başka ricâl eserleri incelenerek İbn Ebî Hayseme’nin râvi tenkidindeki rolü belirginleştirilecektir.

Makalenin ilk araştırma safhasında İbn Ebî Hayseme’nin görüşlerinin bulunabileceği ricâl kaynakları genel olarak taranmış, fakat onların hepsi burada tek tek ele alınmak yerine literatürü ve dönemleri temsil kabiliyeti olanlar ve daha geniş malzeme içerenler seçilerek makale sınırları çerçevesinde değerlendirilmiştir. Buna göre İbn Ebî Hayseme’nin râviler hakkındaki görüşlerini tespitte Târîh'ten sonra önem taşıyan kaynak İbn Ebî Hâtim'in (ö. 327/938) el-Cerh ve't-tádîl'idir. Müstakil başlık altında incelenen bu kitaptan sonra sırasıyla İbn Hibbân el-Büstînin (ö. 354/965) Kitâbü’l-Mecrûhîn'ine, Ebû Ya'lâ el-Halîlînnin (ö. 446/1055) el-İrşâd' 'na ve Hatîb el-Bağdâdînin Târîh'ine bakılacak, ardından Endülüs bölgesinden bir kaynak olarak Ebü'l-Velîd el-Bâcînnin (ö. 474/1081) et-Tádîl ve’t-tecrîh'i ve İbn Asâkir'in Târîhu medîneti Dımaşk’’ değerlendirilecektir. Son olarak ise kendinden önceki ricâl birikimini özgün katkılarıyla yansıtan İbn Hacer'in Tehzîbü̉t-Tehzîb’i incelenecektir. Makalede ulaşılan sonuçların, araştırma safhasındaki genel taramada edindiğimiz kanaatlerle uyum arz ettiği belirtilmelidir.

Konunun incelenmesine geçmeden önce, râvileri tenkit işiyle uğraşanları listeleyen çalı̧malarda İbn Ebî Hayseme’nin konumuna göz atmak faydalı olacaktır. İbn Hibbân ve İbn Adî, İbn Ebî Hayseme'den haberdar olmalarına ve zayıf râvilere dair kitaplarında ona atıf yapmalarına rağmen hadis tenkidinin tarihçesinden bahsettikleri mukaddimelerde onu zikretmemişlerdir. Sehâvî (ö. 902/1497) de el-Mütekellimûn fír-ricâlde İbn Ebî Hayseme’yi yalnızca babası Ebû Hayseme’nin râvileri arasında anmıştır. ${ }^{47}$ Zehebî ise İbn Ebî Hayseme’yi

46 İbn Ebî Hayseme’ye İslâm tarihçiliğinin diğer telif türlerinde yapılan atıflar burada incelenmeyecektir. Fakat belki bir başlangıç noktası olarak, Târîh'in, yazılışından hemen sonra tarihçilerin ilgisiyle karşılaştı̆̆ söylenebilir. Sözgelimi Vekî'in (ö. 306/918) Ahbâru'l-kudât'ı, Târîh' 'in bugün elimizde bulunmayan kısımlarını içerecek şekilde kitaptan nakiller yapar (s. 64, 75, 88, 154, 157, 233, 234, 266, 363, 477, 494, 568, 643, 646, 689). Aynı şekilde Taberî de (ö. 310/923) Târîh'inde İbn Ebî Hayseme'den gelen rivayetlere yer vermiştir (IV, 417, 419, 429, 452, 469; V, 325, 327, 329, 335, 495; VII, 205, 207, 208, 234, 236, 237, 251, 262, 265-268, 281, 295, 311, 345).

47 Sehâvî, el-Mütekellimûn firr-ricâl, s. 103. 
müstakil olarak kaydetmiştir. ${ }^{48}$ Bu veriler önemli olmakla birlikte kişilerin münekkit vasfını belirlemek için yeterli değildir. Zira adı geçen çalışmaların çoğunun kapsamı, özellikle İbn Adî ile Zehebî̉nin listeleri, hadis/râvi tenkidiyle belirgin biçimde ilgilenmeyenleri de içine alacak kadar geniş tutulmuştur. Buralardaki verileri doğrudan ricâl literatürünü esas alarak revize etmek lazımdır.

\subsection{Târîh'te Cerh-Ta'dîle Dair Kayıtlar}

Târîh, sahâbe ve sonraki nesillerden ilmiyle öne çıkmış kişilerin soyları, hocaları ve talebeleri, ibadet hayatları, itikâdî ve siyasî tutumları, ahlâk ve zühd anlayışları vb. hakkındaki haberleri bir araya getirmiștir. Bunlar arasında, râvilerin güvenilir olup olmadıklarına dair nakledilmiş görüşler de bulunmaktadır. Fakat baştan belirtmek gerekir ki, İbn Ebî Hayseme’nin ricâl tenkitçiliğini görebilmek için Târîh'ten ziyade sonraki cerh-ta'dîl müelliflerinin eserlerine bakmak daha isabetlidir. Zira ilk olarak Târîh'in küçük bir kısmı günümüze ulaşmış olup kalan büyük kısmı hâlen kayıptır. İkinci olarak, kitapta cerh-ta'dîle dair notlar bulunsa da kitabın odak noktasını bu notlar oluşturmaz. Nitekim cerh-ta'dîl nakillerinin bir kısmı, isnadda belirli bir râvinin geçmesi üzerine ana akışı bölerek o kişi hakkında bilgi sunmak şeklinde olmaktadır. Eğer bir odak noktası belirlemek gerekirse -ki kitabın geniş muhtevası dikkate alınırsa bunu yapmak ne kadar doğrudur tartışılır- hoca-talebe ilişkilerinin kitapta daha fazla işlenen bir mesele olarak öne çıktığı söylenebilir. Son olarak, güvenilirlikleri tartışma konusu yapılmayan sahâbe biyografilerinin ağırlıkta olması, kitabın cerh-ta‘dîl yönünü kısıtlayan bir özellik olarak değerlendirilebilir.

Râvi değerlendirmeleri bakımından sınırlı bir muhtevaya sahip olan Târîh’in günümüze ulaşan kısmında İbn Ebî Hayseme, açıkça cerh-ta'dîl içeren 170 civarında nakle yer vermiştir. $\mathrm{O}$, eserinin genelinde yaptığı gibi, cerh-ta‘dîl konusunda bizzat görüş belirtmek yerine önceki münekkitlerin kanaatlerini -muhtemelen onaylayarak- nakletmeyi tercih etmiştir. Râvilerin cerh-ta'dîline dair görüşleri en fazla nakledilen kişi Yahya b. Maîn'dir. İbn Ebî Hayseme’nin, çoğunu bizzat Yahya b. Maîn'den işittiği, bir kısmına ise Ahmed b. Hanbel vasitasıyla ulaştığı bu nakillerde Yahya "daîf”, 49 "daîfü'l-hadîs", 50 "sika", 51 "leyse hadîsühû bi-şey’in", 52 "sâlih", 53 "leyse bihî be's", 54 "leyse bi-zâke'l-kavî" ${ }^{55}$ gibi lafızlarla çok sayıda râvinin durumunu

\footnotetext{
48 Zehebî, Zikru men yu'temed kavlühû fi'l-cerh ve't-ta'dîl, s. 193.

49 İbn Ebî Hayseme, Târîh, I, 266 (prg. 924, 925).

50 İbn Ebî Hayseme, Târîh, I, 117 (prg. 142), 131 (prg. 213); III, 56 (prg. 3807).

51 İbn Ebî Hayseme, Târîh, I, 117 (prg. 141), 122 (prg. 165), 129 (prg. 200); II, 323 (prg. 3145); III, 73 (prg. 3882 ), 146 (prg. 4190), 199 (prg. 4495), 217 (prg. 4537), 233 (prg. 4611).

52 İbn Ebî Hayseme, Târîh, I, 123 (prg. 168); III, 181 (prg. 4378), 230 (prg. 4589, 4591).

53 İbn Ebî Hayseme, Târîh, I, 301 (prg. 1076); II, 297 (prg. 3007); III, 191 (prg. 4441).

54 İbn Ebî Hayseme, Târîh, I, 227 (prg. 688, 690); II, 330 (3189); III, 192 (prg. 4444).

55 İbn Ebî Hayseme, Târîh, II, 349 (prg. 3308); III, 204 (prg. 4509).
} 
belirtmiştir. Yahyảnın dışında Vekî‘ b. el-Cerrâh ${ }^{56}$ ve Süfyan b. Uyeyne ${ }^{57}$ gibi münekkitlerden gelen görüşlere de -çok az olmakla birlikte- yer verilmiştir.

Açıkça cerh-tádîl içermemekle birlikte râvi araştırması yapacak olanlara yardımcı olabilecek kayıtların sayısı ise fazladır. Kimlik ve künye tespitleri, başka râvilerle mukayeseler, hoca-talebe ilişkilerine dair bilgiler, bu türden kayıtlara örnek olarak zikredilebilir. Râviden bahsedilmeksizin rivayetler arasındaki farklara dikkat çekildiği de olmuştur. ${ }^{58}$ İbn Ebî Haysemẻnin husûsen cerh-tádîldeki rolünü belirleyebilmek için bu sahaya hasredilmiş olan diğer eserlere başvurmak bir zorunluluktur.

\section{2. İbn Ebî Hâtim'in el-Cerh ve’t-ta'dîl' inin Kaynağı Olarak İbn Ebî Hayseme}

İbn Ebî Hayseme’nin İbn Ebî Hâtim’e ait el-Cerh ve’t-ta'dîl'deki yerini görmeden önce bu kitap hakkında kısa bir bilgi vermek uygun olacaktır. Buhârînin et-Târîhu'l-kebîr'ini esas alan İbn Ebî Hâtim, babası Ebû Hâtim ile arkadaşı Ebû Züra’nın râviler hakkındaki görüşlerinin yanında diğer münekkitlerin ricâle dair kanaatlerini de derlemek için özel bir gayret sarfetmiş, bu amaçla, Yahya b. Maîn’e ve Ahmed b. Hanbele talebelik yapmış olanlarla irtibat kurmuştur. Bir kısmını bizzat bu talebelerden işiterek, bir kısmını da onlarla yazışarak aldığı cerh-tadîl bilgilerini eserinde bir araya getirmiştir. ${ }^{59}$ Ayrıca râvilerin güvenilirlikleriyle alâkalı olmayan bilgileri büyük ölçüde ayıklayarak doğrudan hadis rivayetinde sağlam olup olmadıklarını değerlendirme yoluna gitmiştir. Dolayısıyla el-Cerh ve't-ta'dîl ilk üç asırdaki râvi tenkidi hakkında öncelikli olarak başvurulması gereken kaynaklardandır.

İbn Ebî Hâtim’in mükâtebe yoluyla irtibat kurduğu kişilerden biri İbn Ebî Hayseme’dir. ${ }^{60}$ O, tespitlerimize göre 509 kere ismini zikrettiği İbn Ebî Hayseme’den aldığı haberlerde her zaman "أخبرنا أبو بكر بن أبي خيثمة فيما كتب إلي 61 ifadesini kullanmıştır. Bu haberlerin birkaç istisna dışında tamamı, İbn Ebî Hayseme’nin Yahya b. Maîn başta olmak üzere önceki münekkitlerden yaptığı nakillerdir. İbn Ebî Hayseme, bizzat görüş belirttiği nâdir şahıslardan biri وكان رجل (مل olan Ebü'l-Abbas Ahmed b. el-Haccâc (ö. 222/836) hakkında "doğru sözlü birisiydi صدق (صن demiş, ${ }^{62}$ yine Benî Temîm'den Ebû Muhammed künyeli bir arkadaşını bir isnadın sevki sırasında "güvenilir (ثقة)" diyerek ta dîl etmiştir. ${ }^{63}$ Son olarak ise Ali b. el-Hasan es-Saffâr isimli râviyi "güvenilir olmayan kötü bir râvidir (هو شيخ سوء غير ثقة)" diyerek cerh etmiş-

56 İbn Ebî Hayseme, Târîh, III, 205 (prg. 4511)

57 İbn Ebî Hayseme, Târîh, I, 196-197 (prg. 505).

58 Bk. İbn Ebî Hayseme, Târîh, II, 8-9 (prg. 505).

59 İbn Ebî Hâtim, el-Cerh ve't-ta'dîl, I, ye-elif, ye-be (neşredenin önsözü).

60 Abdurrahman el-Muallimîye (ö. 1966) göre, İbn Ebî Hayseme’nin İbn Ebî Hâtim’e Târîh'inin tamamını göndermiş olması muhtemeldir (İbn Ebî Hâtim, el-Cerh ve't-ta'dîl, I, ye-be).

61 Sayılı birkaç yerde “حدثنا أبو بكر بن أبي خيثمة فيما كتب إلي demiştir ki, bu farklılık mânâyı etkilememektedir.

62 İbn Ebî Hâtim, el-Cerh ve’t-ta'dîl, II, 46. Râvi hakkında İbn Ebî Hayseme dışındaki münekkitler de aynı kanaate sahiptir (İbn Hacer, Tehzîb, I, 19).

63 İbn Ebî Hâtim, el-Cerh ve’t-tádîl, VIII, 194-195. Râvinin ismi bilinmediği için diğer münekkitlerin görüşleri tespit edilememiştir. 
tir. ${ }^{64}$ Ancak el-Cerh nüshalarındaki farklılıktan dolayı son ifadenin İbn Ebî Hayseme’ye aidiyeti kesin değildir. Ona ait bile olsa bu görüş, İbn Maîn’in aynı râvi hakkındaki "güvenilir değildir” şeklindeki kanaatinin pekiştirilmesinden ibarettir.

İbn Ebî Hayseme’nin önceki münekkitlerden naklettiği cerh-ta‘dîl değerlendirmelerinde başlıca kaynağı Yahya b. Maîn'dir. İbn Maîn ile yakınlığına yukarıda işaret edilen İbn Ebî Hayseme, hocasına ait râvi değerlendirmelerini muhtelif ibarelerle rivayet etmiştir. Bazen "sordum (سألت)" gibi hocaya bizzat sorduğuna, 65 bazen de "soruldu (سئل)" 66 gibi kendisi oradayken başkasının sorduğuna işaret eden lafızlarla nakletmiş, bazen de yalnızca "işittim (سمعت)" ifadesini kullanmıştır. ${ }^{67}$ İbn Ebî Hayseme-Yahya b. Maîn ilişkisini gösteren ifadelerden anlaşıldığı kadarıyla, İbn Maîn talebeleriyle ricâl değerlendirmelerini paylaştı̆̆ı meclisler akdetmekte, bazen tek yönlü bazen soru-cevap şeklinde olmak üzere değerlendirmeler yapmaktadır. Hoca-talebe arasındaki bu canlı diyaloglar ilave sorularla bir müzâkere ortamına dönüşebilmektedir. Meselâ Abdülhamîd b. Cáfer el-Ensârî (ö. 153/770) hakkındaki bir müzakerenin gelişmini İbn Ebî Hayseme şöyle anlatır:

Yahya b. Maîn’in şöyle dediğini işittim: "Abdülhamîd b. Ca'fer’i Yahya b. Saîd [el-Kattân] güvenilir, Süfyan es-Sevrî ise zayıf sayardı.”

“Peki senin görüşün nedir?” diye sordum.

"Rivayet ettiği hadislerde bir beis yoktur, o sâlih bir râvidir" dedi. ${ }^{6}$

Bir başka diyalogda bahis mevzuu kişi Yakub b. Humeyd b. Kâsib'dir (ö. 240/854-5). Yine İbn Ebî Hayseme anlatıyor:

İbn Kâsib hakkında Yahya b. Maîn "Güvenilir değildir” dedi.

“Bunu neye dayanarak söylüyorsun?” diye sordum.

“Çünkü o had cezasına uğramıştır” dedi.

"Peki, hadis semâ‘'nda güvenilir değil midir?” diye sordum.

"Bilakis [güvenilirdir]" dedi. ${ }^{69}$

64 İbn Ebî Hâtim, el-Cerh ve’t-ta'dîl, VI, 180-181. Hadiste yalancilıkla itham edilmiş olan Ali b. el-Hasan es-Saffâr hakkında olumlu bir kanaate rastlanmamıștır (bk. İbn Hacer, Lisân, V, 517).

65 İbn Ebî Hâtim, el-Cerh ve’t-ta'dîl, III, 540.

66 İbn Ebî Hâtim, el-Cerh ve't-ta'dîl, III, 499; IV, 383.

67 İbn Ebî Hâtim, el-Cerh ve’t-ta'dîl, IV, 356, 362.

68 İbn Ebî Hâtim, el-Cerh ve’t-ta'dîl, VI, 10. İlave sorularla gelişen bir diğer diyalog için bk. a.g.e., II, 533. Yahya b. Maîn'in meclislerinde başka münekkitlere ait görüşlerin değerlendirme konusu yapıldığı, yine İbn Ebî Hayseme’nin naklettiği şu örnekte de görülür: "Yahya b. Maîn’e, Ahmed b. Hanbel'in Ali b. Âsım için 'güvenilir' dediği söylendi. Yahya, 'Hayır, vallahi onun nazarında asla güvenilir birisi değildi, ondan bir harf bile rivayet etmedi. Bugün nasıl olur da güvenilir olur?' dedi" (İbn Ebî Hâtim, el-Cerh ve’t-ta‘dîl, VI, 199).

69 İbn Ebî Hâtim, el-Cerh ve’t-tádîl, IX, 206. Bu rivayet Târîh'in kendisinde de geçmektedir (İbn Ebî Hayseme, Târîh, I, 296, prg. 1054). 
Yahya b. Maîn’in İbn Kâsib hakkında en başta söylediği görüşe katılmadığı anlaşılan İbn Ebî Hayseme daha sonra Muśab ez-Zübeyrî̀ye giderek aynı râviyi bir de ona sormuş, Muśab Yahya’nın ilk söylediklerini hoş karşılamamış, İbn Kâsib’in güvenilir olduğunu teyit etmiştir. ${ }^{70}$ Görüldüğü gibi İbn Maîn’in çevresindeki İbn Ebî Hayseme’nin de dahil olduğu talebe grubu yalnızca dinleyip itaat eden değil aksi istikametteki görüşleri gündeme getiren, müzakere ortamı oluşturan, hocanın verdiği hükmü sınırlayabilecek notlar düşen kimselerdir. Onlar müstakil bir münekkit olarak pek fazla konuşmamışlarsa da, hocalarının dilinde ifadesini bulan ama oluşumuna bir şekilde katkı yaptıkları ricâl tenkidi birikiminin gölgedeki aktörleri olarak görülebilirler.

İbn Ebî Hayseme’nin Yahya b. Maîn'den naklettiği görüşlerin bir kısmı, hocasının bir isnadın sevki esnasında isnaddaki bir râvi hakkında yaptığı anlaşılan değerlendirmelerdir. Meselâ "Bize Abdülaziz b. Abdüssamed el-Ammî nakletti -ki onda bir beis yoktur- (نا عبد " vb. kalıplarla gelen ifadelerin böyle olması kuvvetle muhtemeldir. İbn Maîn'den birtakım nakiller ise belli bir hocanın talebeleri arasında mukayeseler yapan değerlendirme cümlelerinden oluşur. "Sâbit'ten hadis nakledenler arasında en sağlam kişi Hammâd b. Seleme’dir” gibi cümleler buna örnektir. ${ }^{72}$ Mukayese içeren bu gibi ifadeler doğrudan cerh veya ta'dîl anlamına gelmese de çok sayıda talebesi olan ve kendilerinden nakledilen hadisler arasında farklılıklar görülen tanınmış muhaddisler sözkonusu olduğunda son derece faydalı birer veridir.

İbn Ebî Hayseme, Yahya b. Maîn dışındaki münekkitlerin görüşlerini de onlara varan isnadlarla nakletmiştir. Şu'be b. el-Haccâc (ö. 160/776), ${ }^{73}$ Vekî́ b. el-Cerrâh, ${ }^{74}$ Yahya b. Saîd el-Kattân, ${ }^{75}$ Süfyan b. Uyeyne, ${ }^{76}$ İbn Ebî Hayseme’nin babası Ebû Hayseme ${ }^{77}$ ve Ahmed b. Hanbel ${ }^{78}$ gibi isimlerden gelen bu nakiller, İbn Ebî Hayseme’nin eksik olan kendi Târîh'inde sınırlı biçimde görülen cerh-ta‘dîl faaliyetini birkaç nesil öncesine uzanacak şekilde gözler önüne sermektedir.

70 İbn Hacer, Tehzîb, IV, 441. Zübeyrî, İbn Kâsib’in, Ebû Tâlib’in soyundan gelen bazı aşırı Tâlibîler tarafından cezalandırıldığını söylemiş, dolayısıyla bunun cerh sebebi sayılamayacağına işaret etmiştir. Fakat Tehzîb'deki biyografide görüldüğü üzere, İbn Kâsib zabtındaki kusurlar sebebiyle de tenkide uğramıştır. İbn Hacer bu tenkitlere rağmen onu, "zaman zaman hata yapan doğru sözlü biri (صدوق ربما وهم)" diye nitelemişse de Şuayb el-Arnaût (ö. 2016) ile Beş̧̧̂ิr Avvâd Márûf, İbn Kâsib’i rivayetleri ancak mütâbaat için elverişli olan zayıf râvilerden saymıştır (Tahrîr, IV, 125).

71 İbn Ebî Hâtim, el-Cerh ve't-ta'dîl, V, 388.

72 İbn Ebî Hâtim, el-Cerh ve't-tádîl, III, 141; ayrıca bk. IV, 370.

73 İbn Ebî Hâtim, el-Cerh ve’t-ta'dîl, V, 179.

74 İbn Ebî Hâtim, el-Cerh ve't-ta'dîl, IX, 59.

75 İbn Ebî Hâtim, el-Cerh ve’t-tádîl, VI, 75, 253-254, 264; VIII, 146.

76 İbn Ebî Hâtim, el-Cerh ve't-ta'dîl, IV, 417, 475, VIII, 313.

77 İbn Ebî Hâtim, el-Cerh ve't-ta‘dìl, III, 12.

78 İbn Ebî Hâtim, el-Cerh ve't-ta'dîl, IV, 100. 


\section{3. İbn Hacer'in Tehzîbü’t-Tehzîb'inden Önceki Kaynaklarda İbn Ebî Hayseme}

İbn Ebî Hayseme'den gelen rivayet ve görüşlere el-Cerh ve’t-ta'dîl'den sonraki ricâl eserlerinde de yer verilmiştir. Meselâ İbn Hibbân, Muhammed b. Salih el-Hanbelî (ö. ?) vasitasıyla ulaştığ İbn Ebî Hayseme’ye, lafızları birbirine benzeyen yoğun atıflar yapmıştır. ${ }^{79}$ İlgili yerlerin büyük çoğunluğunda İbn Ebî Hayseme, Yahya b. Maîne bir râvinin sorulması (veya bazılarında bizzat kendisinin sorması) üzerine Yahya’nın verdiği kısa cevabı nakletmektedir. Kısmen farklı bir örnekte Yahya, Musa b. Ubeyde isimli râvinin zayıf sayılma sebebinin Abdullah b. Dînâr'dan (ö. 127/745) münker hadisler nakletmesi olduğunu kaydeder. ${ }^{80}$

İbn Ebî Hayseme’nin nakillerine yer veren bir diğer çalışma Ebû Ya'lâ el-Halîlînnin el-İrşâd’ıdır. Halîlî, İbn Ebî Hayseme’nin eserinin hadisçi olsun olmasın pek çok ismi içerdiğini teslim etmekle birlikte kitaptan yalnızca bu alanda bilgi sahibi olanların yararlanabileceğini söylemiştir. ${ }^{81} \mathrm{O}$, yaklaşık 40 yerde -bazen uzun pasajlarla- İbn Ebî Hayseme’den nakilde bulunur. Buradaki rivayetlerde de İbn Ebî Hayseme önceki muhaddislerden çeşitli konulara dair haberler nakletmekte, kendisi müstakil olarak bir râvinin cerhini veya ta‘dîlini yapmamaktadır. ${ }^{82}$

İbn Ebî Hayseme’nin Târîh'ini yakından bildiği yukarıda belirtilen Hatîb el-Bağdâdî, birden fazla kanalla ulaştığı hemşehrisinin eserine bolca atıf yapmıştır. İbn Ebî Hayseme’nin Ahmed b. el-Haccâc hakkındaki ta'dîlini İbn Ebî Hâtim gibi o da nakletmiş, ${ }^{83}$ ayrıca bazı râvilerin kimliğini, vefat tarihini ve yerini İbn Ebî Hayseme’nin görüşleriyle belirlemiştir. ${ }^{84}$ İbn Ebî Hayseme’nin haklarında bilgi verdiği râvilerin neredeyse tamamının kendisi hayattayken vefat etmiş kişiler olması dikkat çeker. O, döneminde bizzat şahit olduğu veya duyduğu vefatları günlerine kadar titizlikle kaydetmiş gibidir. Ancak râvilerin cerh-ta'dîli sözkonusu olduğunda İbn Ebî Hayseme yine Yahya b. Maîn başta olmak üzere kendinden önceki münekkitlerin râvisi konumundadır. O, kişilerin hadis rivayetindeki güvenilirlik durumlarına dair değerlendirmeleri İbn Maîn'den genellikle kısa ifadelerle rivayet ederek ortaya koymuştur. ${ }^{85}$

İbn Ebî Hayseme’den gelen nakiller Ebü'l-Velîd el-Bâcînin Sahîhu'l-Buhârînin ricâli üzerine kaleme aldığg et-Ta'dîl ve’t-tecrîh adlı eserinde de yer almıştır. Bâcî yaklaşık elli yerde râvinin güvenilirliği, kimliği, vefat tarihi, ilmî vasıfları yahut başka kimselerle mukayesesi

79 İbn Hibbân, Kitâbü'l-Mecrûhîn, I, 193, 202, 211, 220, 223, 266, 334, 348, 393, 448, 465, 513; II, 179, 193, 208, 212, 247, 283, 285, 356, 423, 433, 449, 453, 476, 485, 502.

80 İbn Hibbân, Kitâbü'l-Mecrûhîn, II, 242.

81 Halîlî, el-írşâd, I, 155.

82 Mâlik, Ebû Hayseme ve İbn Maîn gibi isimlerden naklettiği bazı cerh-tađdîl görüşleri için bk. Halîlî, el-İrşâd, I, 302; II, 588, 589; III, 882, 926, 933, 936, 944, 952-3.

83 Hatîb, Târîh, V, 187.

84 Hatîb, Târîh, IV, 240; X, 43; XI, 540; XII, 14, 306, 412; XIV, 19, 509; XVI, 89.

85 İbn Maîn'den naklettiği cerh-ta‘dîller için bk. Hatîb, Târîh, IV, 253; VII, 176, 379; VIII, 181; IX, 117; X, 345; XI, 479; XII, 167, 207; XIII, 18, 405. 
gibi konulara dair olmak üzere İbn Ebî Hayseme’nin nakillerine başvurmuştur. ${ }^{86}$ Bu nakiller arasında Târîh'in günümüze ulaşmış parçaları içinde geçenler olduğu gibi geçmeyenler de bulunur. Bâcînnin kitabında başlıca kaynak olarak kullandığı eserlerden biri İbn Ebî Hâtim’in yukarıda bahsedilen el-Cerh ve't-tadîl'idir. ${ }^{87}$ İbn Ebî Hayseme’den nakillerin el-Cerh ve'tta'dîl'deki yoğunluğu ve Bâcînnin istifade ettiği kaynaklara ulaşan isnadlarını verdiği yerde Târîh'i zikretmemesi ${ }^{88}$ dikkate alınırsa, Bâcînin sözkonusu nakillere el-Cerh ve't-ta'dîl üzerinden ulaşmış olma ihtimali güç kazanmaktadır. Bâcînin İbn Ebî Hayseme’den rivayetleri şekil ve muhteva bakımından Târîh'teki rivayetlerle örtüşür. Burada da İbn Ebî Hayseme, Yahya b. Maîn başta olmak üzere kendinden önceki muhaddislere ve tarihçilere uzanan isnadlarla onların görüşlerini nakletmektedir. İstisnâ olarak, yukarıda ismi geçen Ahmed b. el-Haccâc'in ta'dîli bizzat İbn Ebî Hayseme’den nakledilmiştir. ${ }^{89}$

Cerh-tadîlle ilgili olsun veya olmasın İbn Ebî Hayseme’den gelen rivayetlere en fazla yer veren müellif Ebü'l-Kasım İbn Asâkir olmuştur. O, Târîhu medîneti Dımaşk'ta yüzlerce yerde ismini andığ İ̉bn Ebî Hayseme’nin nakillerini isnadlı olarak vermiştir. ${ }^{90}$ Eserin Şam’ın coğrafî özelliklerinden siyer-i Nebî̀ye, İslâm fetihlerinden peygamberler tarihine ve nihayet ulemâya kadar uzanan geniş kapsamı, kendisi gibi geniş kapsamlı olan Târîh'ten yaptığ yoğun nakillerin başlıca sebebi olarak görülebilir. Ne var ki nicelik yönünden artmış olan bu nakillere cerh-tadîl açısından bakıldığında, önceki kaynaklardan kayda değer bir farklılık gözlenmemekte, dolayısıyla İbn Ebî Hayseme’nin ricâl tenkitçiliği hakkında yukarıdaki çalışmalardan edinilen izlenim pekişmektedir.

\subsection{Tehzîbü’t-Tehzîb'de İbn Ebî Hayseme’ye Atıflar}

İbn Ebî Hayseme’nin ricâl tenkitçiliğindeki yerini belirleyebilmek için son olarak İbn Hacer'in Tehzîbü't-Tehzîb'ine bakmak gerekmektedir. Bilindiği gibi bu eser, Abdülganî el-Makdisî el-Cemmâîlı̂nin (ö. 600/1203) el-Kemâl'i ile başlayan Kütüb-i sitte ricâline mahsus literatürün en yaygın bilinen örneğidir. ${ }^{91}$ Buradaki Tehzîbütt-Tehzîb merkezli incelemede ulaşılan sonuçlar, mezkûr literatürdeki diğer kitaplar için de aşağı yukarı geçerli sayılabilir. ${ }^{92}$ Tehzîbü̈t-Tehzîb’e bakmadan önce, bu kitabın dayandığı Mizzînnin (ö. 742/1341) Tehzîbü'l-Kemâl'inden bir hususun altını çizmek gerekir. Mizzî râviler hakkında yazılmış,

86 Meselâ bk. Bâcî, et-Tádîl ve’t-tecrîh, I, 333, 357; II, 498, 504, 518, 561; III, 1101, 1106, 1122, 1125.

87 Bâcî, et-Ta'dîl ve't-tecrîh, I, 275.

88 Bâcî, et-Ta'dîl ve't-tecrîh, I, 273-278.

89 Bâcînin İbn Ebî Hâtim kanalıyla yaptığı bu nakil için bk. et-Tádîl ve’t-tecrîh, I, 317 (no. 6).

90 Yalnızca ilk ciltten örnekler için bk. İbn Asâkir, Târîh, I, 44, 45, 52, 153, 155, 156, 188, 241, 250, 299, 361. İbn Ebî Hayseme'ye ait bir künye ve neseb tespiti için bk. a.g.e., X, 41.

91 el-Kemâl üzerine oluşmuş literatür Kütüb-i sitte ricâliyle sınırlı olsa da müteahhir dönem râvi tenkidinin gerçekleştirildiği en önemli damarlardan biridir. Literatür hakkında özet bilgi için bk. Özşenel, "Bir Kemâlin Hikâyesi", s. 155-161.

92 Tehzîbü't-Tehzîb dışındaki eserler arasında, İbn Hacer'in de müracaat ettiği Moğultay b. Kılıç'ın (ö. 762/1361) İkmâlü Tehzîbi'l-Kemâl'inin nisbeten önemli gözüktüğü söylenebilir. 
“ümmehât” diye adlandırdığı on temel eseri sayarken altıncı sırada İbn Ebî Hayseme’nin Târîh'ini zikretmiştir. ${ }^{93}$ Dolayısıyla Târîh, el-Kemâl üzerine oluşturulmuş ricâl çalışmalarının kaynak olarak kullandığı başlıca eserler arasında yer almaktadır. Sözkonusu literatürü oluşturan en önemli isimlerden olan İbn Hacer de tabiî olarak İbn Ebî Hayseme’ye pek çok kez müracaat etmiştir.

Tehzîbü't-Tehzîb'de Târîh'e doğrudan ismiyle atıfta bulunulan yerlerde ${ }^{94}$ verilen bilgilerden bazıları bugün Târîh'in matbû olan kısımlarında geçmeyen pasajlardır. ${ }^{95}$ İbn Ebî Hâtim'in el-Cerh ve’t-ta'dîl'i İbn Ebî Hayseme’nin katkısını görmek için ne derece mühim bir kaynaksa, İbn Hacer’in Tehzîb’i -veya el-Kemâl üzerine oluşmuş literatür- de daha geç döneme ait olmakla birlikte aynı ölçüde önemlidir. ${ }^{96}$

Tehzîb'de râvilerin güvenilirliklerine dair İbn Ebî Hayseme’nin kendisine nispet edilen görüşler el-Cerh ve't-ta'dîl'de olduğu gibi azdır. İbn Ebî Hayseme, yukarıda geçen Ahmed b. el-Haccâc hakkındaki tevsikinin yanı sıra, ${ }^{97}$ Zübeyr b. Saîd isimli râvinin İbnü'l-Münkedir'den münker rivayetlerinin bulunduğunu belirtmiş; ${ }^{98}$ Şabînin, ismini açıkça zikrettiği hocasının sika sayıldığını, dolayısıyla Hârice b. es-Salt’ın sağlam olduğunu söylemiştir. ${ }^{99}$ Ayrıca Üneys b. Ebû Yahya'yı tevsik etmiş ${ }^{100}$ ve Katâde’nin (ö. 117/735) en sağlam râvileriyle ilgili değerlendirme yapmıştır. ${ }^{101}$ Ancak son iki değerlendirme, İbn Ebî Hayseme’nin kendi Târîh'inde Yahya b. Maîn'e ait gözükmektedir. ${ }^{102}$ Dolayısıyla -nüsha kaynaklı bir problem sözkonusu değilse- ya İbn Hacer aslen İbn Maîne ait olan bir görüşü râvi konumunda olan İbn Ebî Hayseme’ye atfetmiştir ya da İbn Ebî Hayseme hocasından duyup naklettiği bir değerlendirmeye katılıp sonradan bunu kendi görüşü olarak takdim etmiştir.

İbn Ebî Hayseme cerh-ta'dîl konusunda Tehzîb’de de Yahya b. Maîn’in râvisi olarak öne çıkar. ${ }^{103}$ Gerek İbn Ebî Hâtim gerek İbn Hacer, pek çok yerde Yahya b. Maîn’in talebelerinin hocalarından naklettiği görüşleri peşpeşe zikrederek bunları bir bütünlük içerisinde değerlendirdiklerini hissettirmişlerdir. Öyle ki, İbn Hacer bazen İbn Ebî Hayseme’nin İbn

93 Onun saydığı ilk beş eser sırayla İbn Ebî̀ Hâtim'in el-Cerh ve’t-ta'dîl'i, İbn Adî̉nin el-Kâmil'i, Hatîb'in Târîhu Bağdâd'1, İbn Asâkir'in Târîh'i ve İbn Sa'd’ın Tabakât’idır (Mizzî, Tehzîbü'l-Kemâl, I, 152-154).

94 Meselâ bk. İbn Hacer, Tehzîb, I, 148, 171, 270, 463, 467, 622; II, 82, 320, 354; III, 277, 344; IV, 433.

95 Telib b. Sa'lebe (Tehzîb, I, 257), Câbir b. Zeyd (Tehzîb, I, 280), Husayn b. Nümeyr (Tehzîb, I, 447) ve Abdullah b. Şakîk el-Ukaylî (Tehzîb, II, 354) hakkında İbn Ebî Hayseme’den nakledilen bilgiler bunlardan yalnızca birkaçıdır.

96 el-Kemâl ve onun üzerine oluşmuş literatürün pek çok yönden el-Cerh ve’t-ta'dîlden etkilendiği burada unutulmamalıdır. Yukarıda Mizzînin “ümmehât” listesinin başında bu eseri zikretmiş olması sebepsiz değildir.

97 İbn Hacer, Tehzîb, I, 19.

98 İbn Hacer, Tehzîb, I, 625. Burada görüldüğü üzere râvi, münekkitlerin çoğunluğu tarafından zayıf bulunmuştur.

99 İbn Hacer, Tehzîb, I, 512. Hârice, üst derecede sağlam olmamakla birlikte "sadûk denilebilecek (محله الصدق)" râvilerden sayılmıștır (Zehebî, el-Kâşif, II, 338).

100 İbn Hacer, Tehzîb, I, 192. Üneys hakkındaki tevsik, onu güvenilir bulan diğer münekkitlerin kanaatleriyle uyumludur.

101 İbn Hacer, Tehzîb, II, 34.

102 İbn Ebî Hayseme, Târîh, II, 83 (prg. 1835), 321 (prg. 3131-3).

103 Yüzlerce örnek içinden bk. İbn Hacer, Tehzî̀, I, 382, 548, 592, 615; II, 417, 482, 487, 490; III, 22, 29, 80, 163, 525; IV, $322,365,368,388,400$. 
Maîn'den naklettiği görüşü Abbâs ed-Dûrî (ö. 271/884) başta olmak üzere diğer râvilerin nakilleriyle birleştirerek vermiştir. ${ }^{104}$

İbn Ebî Hayseme’nin Yahya b. Maîn'den buradaki nakilleri, el-Cerh ve’t-ta'dîl'de olduğu gibi, İbn Maîn'in meclisleri hakkında fikir vericidir. Talebeleri Yahya’ya doğrudan râvilerin durumunu sordukları gibi ondan belirli râvileri birbirleriyle mukayese etmesini istemişler, ${ }^{105}$ bazen râvinin hangi sebeple eleştirildiğini sormuşlar, ${ }^{106}$ bazen de başka bir münekkidin kanaatini ona arz etmişlerdir. ${ }^{107}$ Soruların çeşitliliğine bağlı olarak İbn Maîn’in etrafındakilere anlattıkları da hadis rivayetinin muhtelif konularını ilgilendirecek biçimde zenginlik gösterir. O, yukarıdaki türden sorulara cevap verdiği gibi iki râvi arasındaki inkıtâya dikkat çekmiş, ${ }^{108}$ bazen de belirli kişilerden hadis dinlemeyi talebelerine yasaklamıştır. ${ }^{109}$ İbn Ebî Hayseme de Yahya’nın yakın talebelerinden biri olarak bu meclislerde bulunmuş ve duyduklarını kaydederek kendinden sonrakilere aktarmıştır. ${ }^{110}$

İbn Ebî Hayseme Tehzîb'de ricâlle ilgili olarak cerh-ta'dîlden ziyade -veya en az onunla eşdeğer biçimde- râvilerin vefat yılları, kimlikleri, tabakaları ve bizzat yetişip yetişemedikleri hocaları hakkında verdiği bilgilerle öne çıkmıştır. Râvilerin vefat yılları yahut hangi halife zamanında öldükleri tartışılırken başka tarih yazarlarının yanı sıra İbn Ebî Hayseme’nin görüşleri zikredilmiş, ${ }^{111}$ kimliklerini belirginleştirmek üzere künyeleri ve akrabalık yahut

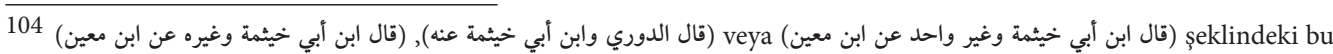
nakiller için bk. İbn Hacer, Tehzîb, I, 151, 225; II, 400; III, 197, 548; IV, 132, 288, 532.

105 İbn Hacer, Tehzîb, I, 290.

106 İbn Hacer, Tehzîb, II, 114.

107 İbn Hacer, Tehzîb, II, 573; III, 280.

108 İbn Hacer, Tehzîb, III, 429; IV, 472.

109 İbn Hacer, Tehzîb, I, 348.

110 Yahya b. Maîn'in etrafında İbn Ebî Hayseme’nin de dahil olduğu talebelerinin katılımıyla oluşan ricâl tenkidi birikimi hakkında yapılacak her türlü çalışma, hadis tenkidinin mahiyetine ışık tutacaktır. İbn Maîn'in Târîh'ini neşreden Ahmed Muhammed Nur Seyf'in esere yazdığı mukaddime, Yahya’nın cerh-ta'dîl meclisleri ve orada konuşulanların tedvini hakkında kıymetli bilgiler içermekte olup sonraki Arapça ve Türkçe literatürü bâriz biçimde etkilemiş, standart referans kaynağı haline gelmiştir. Nur Seyf’in, cerh-ta‘dîlin tedvin tarihçesinin yanı sıra Yahya’nın ilmî biyografisi, meclislerinde hadisi inceleme usûlü, muhtelif talebelerine ait Târîh rivayetlerinin öne çıan özellikleri, Bağdatlı olan ve olmayan öğrencilerinin nakil tarzları arasındaki farklar gibi mühim konuları içeren mukaddimesi için bk. Yahya b. Maîn ve Kitâbühû et-Târîh, I, 3-212. Son dönemde yapılmış iki önemli derleme çalışması da bu bağlamda faydalıdır. Bunlardan birincisi Mevsûatü akvâli Yahya b. Maîn, İbn Maîn'in 5000'e yakın râvi ve bazı illetli hadisler hakkındaki görüşünü her talebesinden ayrı ayrı naklederek bir araya getirmiştir. Değerlendirilen râvi ismine göre alfabetik olan çalışma, İbn Maîn’in bir kişi hakkındaki görüşlerini tek bir yerde görme imkanı sunduğu gibi Yahya'dan gelen nakiller arasındaki uyum ve farkları görmek için de son derece kullanışlıdır. İkinci çalışmada ise İbn Maîn'in beş talebesinin hocalarından naklettikleri "suâlât” ve "tarih"ler Mevsûatü Târîhi İbn Maîn: Hamsü rivâyât adıyla bir arada neşredilmiştir -beş talebenin içerisinde İbn Ebî Hayseme bulunmaz. İndeksi bulunmayan eser, Yahya’nın değerlendirdiği râvilerden ziyade meclisinde gelişen soru-cevap şeklindeki diyalogları ve talebelerin farklı nakil tarzlarını görmek için kullanışlıdır.

Türkiye'de yapılmış yüksek lisans tezlerinden ikisi Yahya b. Maîn ve eserleri hakkında derli toplu bilgi sunmakla birlikte, İbn Maîn’in cerh-ta'dîl görüşlerini belirttiği meclislerin işleyişi, talebelerin kayıt alma ve tedvin şekilleri gibi konulara az temas etmiştir (Mustafa Işık, Yahya bin Maîn’in Hayatı ve Hadis İlmindeki Yeri; Erdinç Ahatlı, Yahya $b$. Maîn ve Cerh-Ta'dildeki Metodu). Bu konulara, Yahya'dan nakledilen suâlâtları türünün diğer örnekleriyle beraber inceleyen şu çalışmada daha ayrıntılı olarak değinilmiştir: Tatlı, Rical Bilgisinin Tespiti, s. 82-143.

111 İbn Hacer, Tehzîb, I, 45, 66, 634; II, 92, 568, 581; IV, 37, 92, 101, 159, 257, 287, 673, 690. 
kabile bağları İbn Ebî Hayseme’ye atıfla ortaya konulmuştur. ${ }^{112}$ Râviler zaman zaman birbirleriyle karıştırıldığından, belirtilen özelliklerinin doğru tespiti önem arz etmektedir. Aynı şekilde tabakalarının da bilinmesi gereklidir. Nitekim İbn Ebî Hayseme özellikle sahâbîliği tartışmalı olan kimseler sözkonusu olduğunda İbn Hacer tarafından dikkate alınan isimlerdendir. ${ }^{113}$ Râvilerin belirli hocalardan hadis dinleyip dinlemediği hakkında da birkaç yerde İbn Ebî Hayseme’nin görüşü zikredilmiştir. ${ }^{114}$ Bu tür bilgiler doğrudan cerh-ta'dîle dair hükümler olmasa da râvilerin güvenilirliklerini araştırırken işe yarayan ve tarihçilik nosyonu gerektiren mühim detaylardır. Buralarda İbn Ebî Hayseme, cerh-ta'dîl nakillerinden farklı olarak, önceki âlimlere atıf yapmadan genellikle doğrudan kendisi görüş belirtmektedir. Bu görüşlerin orijinalliği ve isabeti ayrı bir konudur; ancak cerh-ta'dîl hükümleri ile diğer bilgiler arasında böyle bir farklılığın olduğu ortadadır.

Tehzîb'deki tablo el-Cerh ve’t-ta'dîl'deki tabloyu teyit etmektedir. Şu farkla ki, İbn Ebî Hayseme’nin ricâl ilmine katkısı ve bunun çeşitliliği, hususen cerh-ta‘dîli merkeze alan İbn Ebî Hâtim'in eserine kıyasla Tehzîb'de çok daha belirgin biçimde yansıtılmıştır. Şahısların hadis rivayetindeki güvenilirliklerine dair kısa notların ağırlıkta olduğu el-Cerh ve't-ta'dîl, elKemâl çizgisinde gelişen literatürün başlıca kaynağı olsa da el-Kemâl sonrasındaki eserler daha kapsamlı bir biyografi muhtevasına sahip olduklarından ve belki de geç yazıldıklarından ötürü daha geniş bir perspektifi yansıtır. Dolayısıyla kişilerin künyeleri, akrabalık bağları, memleketleri, tabakaları, doğum ve vefat yerleri ve yılları, hocaları ve talebeleri gibi konularda zengin malzeme içeren el-Kemâl ve sonrasındaki literatürde İbn Ebî Hayseme’nin hadisçi-tarihçi kişiliği tüm boyutlarıyla görülebilmektedir.

\section{Târîh'te Râvilerin Neseblerine ve Kardeşlik Bağlarına Dair Kayıtlar}

Yukarıda gösterildiği gibi, İbn Ebî Hayseme’nin hadis ricâli sahasına yaptığı katkı cerhta'dîl bilgilerinin intikaliyle sınırlı olmayıp râvilerin neseblerine dair bilgi sunmayı da kapsamaktadır. Cahiliye dönemine kadar uzanan bir geçmişe sahip olan neseb bilgisi Araplar için son derece önemlidir ve erken dönem İslâm tarihçiliğinin ilgilendiği temel konulardan biri olmuştur. ${ }^{115}$ "Nessâbe" denilen müstakil uzmanları bulunacak kadar gelişmiş olan bu inceleme sahası hadisçiler tarafından da yakın bir ilgi görmüştür. Sahâbeden başlamak üzere hadis rivayetinde rol oynamış kimselerin aile ve kabile irtibatlarını inceleyen ricâl âlimleri, ulaştıkları bilgileri çeşitli meselelerde kullanmışlardır. Meselâ bir kişinin sahâbî olup olmadığını veya İslâm’a giriş zamanını tespitte başka karînelerin yanı sıra neseb kayıtlarından

\footnotetext{
112 İbn Hacer, Tehzîb, II, 525; III, 377, 385; IV, 301, 473, 686. İbn Ebî Hayseme’nin râvilerin nesebleri ve kardeşleri hakkındaki açıklamaları aşağıda detaylıca ele alınacaktır.

113 İbn Hacer, Tehzîb, I, 99, 638; III, 428, 474.

114 İbn Hacer, Tehzîb, II, 113, 548-549; IV, 345.

115 Bu konu hakkında bk. Önkal, “Araplarda Ensâb İlmi ve İslâm Târîhi Açısından Önemi”, s. 117-132.
} 
yararlanılmıștır. ${ }^{116}$ Tâbiîne ve sonraki râvilere dair neseb bilgisinin en önemli fonksiyonu ise râvinin güvenilirliğini belirlemenin ön şartı olan kimlik tespitine yardımcı olmasıdır. Bu sayede râvilerin başkalarıyla karıştırılmasının önüne geçilerek kimlik bilgileri netleştirilmekte ve ardından rivayetlerinin incelenmesine geçilmektedir.

Târîh'in hadis ricâli ve nesebleri hakkında temâyüz ettiği belki de en dikkat çekici yön kardeş râviler hakkında sunduğu bilgilerdir. ${ }^{117}$ İbn Ebî Hayseme’nin cerh-tadîl birikimini yukarıda inceledikten sonra, onun cerh-tácîl hâricinde katkı yaptığı ricâl ilimlerine bir örnek olmak üzere kardeş râvilere dair görüşlerinin müstakil olarak incelenmesi uygun olacaktır. Kardeşlik merkezli neseb bilgisinin hadisçiler ve tarihçiler arasındaki ortak ilgi alanlarından birini oluşturmasına rağmen çağdaş araştırmalarda pek gündeme getirilmemiş olması, bu tercihin bir diğer sebebi olarak zikredilebilir.

Hadis usûlünde "márifetü'l-ihve ve'l-ahavât" diye anılan kardeş râviler bilgisi, Hadis ilminde birkaç açıdan önem taşımaktadır. Bu bilgi türü, usûl kitaplarında vurgulandığı üzere, kardeş olmayan râvilerin aynı ismi taşıyan babaları sebebiyle kardeş zannedilmelerinin önüne geçer. ${ }^{118}$ Buna bir örnek olarak İbn Ebî Hayseme’nin Yahya b. Maîn'den yaptığı şu nakil zikredilebilir: "İshak b. Râşid Cezîreli, Ma'mer b. Râşid ise Basralıdır, aralarında bir akrabalık bağı yoktur." ${ }^{119}$ Kardeşlik bilgisinin bir diğer fonksiyonu, hadisi ulaşılabilecek en kadim kaynaktan (hocadan) alarak isnadı kısa tutmak arzusuyla alâkalıdır. Âlî isnad üzerindeki bu vurgu sebebiyle kişinin kendisine yakın yaşlardaki râvilerden hadis nakletmesi sık rastlanan veya arzu edilen bir durum değildir. Dolayısıyla râvinin bilhassa aynı tabakadaki kardeşinden rivayet etmesi durumunda hocasının başka biri zannedilmesinin önüne geçmek üzere isnadda peşpeşe gelen râviler arasındaki kardeşlik bağ vurgulanmıştır. Meselâ Muhammed b. Müzâhim’in (ö. ?) kardeşi Dahhâk’tan (ö. 105/723) naklettiği rivayette Dahhâk'tan önce "kardeşinden (عن أخيه)" denilmesi, Muhammed'in belki bizzat yetişebileceği bir hocadan kardeşi Dahhâk vasıtasıyla rivayet ettiğini teyitle vurgulamaktadır. ${ }^{120} \mathrm{Ha}$ dis usûlü eserlerinde "márifetü’l-ihve ve'l-ahavât"1n "rivâyetü'l-karîn", "müdebbec", "rivâyetü’l-âbâ ani'l-ebnâ” gibi konularla peşpeşe ele alınması da kardeşlik bilgisine yüklenen işlevin bunlarla yakından irtibatlı olduğunu göstermektedir. ${ }^{121}$

Öte yandan, özellikle "falancanın kardeşi olan falanca (فلان أخو فلان)" şeklindeki kullanımlarda basit olarak râvinin kimliğini netleștirmek de istenmektedir. Yalnızca ismi ve baba adı verilen bir râvinin başkalarıyla karıştırılma ihtimaline karşı kardeşi de ihtiyaten zikredilmektedir. Ayrıca tanınmış muhaddislerin ailevî irtibatları hakkında da bu gibi

116 İbn Ebî Hayseme’nin neseb bilgisini sahâbe bağlamında kullanımı için bk. Gökçe, İbn Ebî Hayseme’de Sahabe Bilgisi, s. 61-63, 71-74.

117 Târîh'in mevcut neşrinin I, 85-139. sayfaları bu türden bilgilerden oluşmaktadır.

118 Süyûtî, Tedrîb, V, 280.

119 İbn Ebî Hayseme, Târîh, I, 129 (prg. 201).

120 İbn Ebî Hayseme, Târîh, I, 104 (prg. 80).

121 Meselâ bk. İbnü's-Salâh, Ulûmü'l-hadis, s. 310; Süyûtî, Tedrîb, V, 280. 
kayıtlarla ilginç verilere ulaşılabilmektedir. Meselâ meşhur tâbiî Yahya b. Saîd el-Ensârînin (ö. 143/760) iki, Hemmâm b. Münebbih’in (ö. 132/750?) ise üç (erkek) kardeşinin olduğunu isimleriyle birlikte öğrenmekteyiz. ${ }^{122}$ Herhâlükârda, râvilerin nesebleri, tabakaları, memleketleri ve meslekleri hakkında dakik bilgilerin yazıldığg bir vasatta kardeşlik bağlarının da özenle kaydedildiği görülmektedir.

Kardeş râvilere dair Târîh’te geçen kayıtlar farklı şekillere sahiptir. Bazıları, "Saîd b. Mesrûk es-Sevrînin erkek çocukları Süfyan, Ömer ve Mübarek’tir” ${ }^{123}$ tarzındayken bazıları da "Zübeyd b. es-Salt ve Kesîr b. es-Salt kardeştir" ${ }^{24}$ şeklinde ifade edilmiştir. Ayrıca bu bilgilere mesned teşkil eden isnadlı rivayetler de zikredilmiştir. Meselâ Hişâm b. Hassân ile Abdullah b. Hassân’ın kardeş olması, İbn Ebî Hayseme’ye naklettiği bir hadiste Ebû Seleme et-Tebûzekînnin “bize Hişam b. Hassân’nn kardeşi olan Abdullah nakletti (مبد) نا عبداله بن حسان أخو rivayetiyle tespit edilmiştir. ${ }^{125}$ Kardeşlik bazen de önceki bir muhaddisin isnad sevki esnasında değil de doğrudan ricâlden bahsederken yaptığı açıklamalarla belirlenmiştir. Yahya b. Maîn’in “Abdullah el-Müzenînin oğulları olan Bekir ve Alkame kardeştirler” cümlesi bu tip ifadelere örnektir. ${ }^{126}$

İbn Ebî Hayseme’nin “márifetü'l-ihve ve’l-ahavât”la ilgili bölümünün başlıca kaynakları Yahya b. Maîn ve Ali b. el-Medînîdir. Konuyla ilgili kısmın sonunda, yazarın "Zannederim ki bunları Yahya b. Maîn’e arz etmişim, çünkü kitabımın bazı yerlerinde ondan nakledilmiş sözler bulunmaktadır" 127 demesi, ilgili bölümün çok kuvvetli bir ihtimalle İbn Maîn’in onayından geçtiğine işaret eder. İbn Maîn’in genel olarak isnadları zikrederken kardeşlik ilişkilerini vurgulamaya özen gösterdiği görülmektedir. İbn Ebî Hayseme’nin istifade ettiği diğer kaynak ise "ma'rifetü’l-ihve" ye dair yazdığı kitabı günümüze ulaşmış olan Ali b. el-Medînîdir. ${ }^{128}$ Târîh'teki ilgili kısım ile Ali b. el-Medînînin bugün matbû olan kitabı arasında anahatlarıyla yapılacak bir mukayese, İbn Ebî Hayseme’nin İbnü'l-Medînînin çalışmasından istifade ettiğini göstermeye kâfidir. Meselâ İbn Ebî Hayseme’nin “بلغني) bana ulaştı ki” diyerek kaydettiği kardeş râvilerin çoğu, muhteva ve zikredilme sırası dahil İbnü’l-Medînînin eserinde

122 İbn Ebî Hayseme, Târîh, I, 86 (prg. 7), 93-94 (prg. 38).

123 İbn Ebî Hayseme, Târîh, I, 88 (prg. 16)

124 İbn Ebî Hayseme, Târîh, I, 102 (prg. 76).

125 İbn Ebî Hayseme, Târîh, I, 103-104 (prg. 79).

126 İbn Ebî Hayseme, Târîh, I, 122 (prg. 164). Yazarın kardeş râvileri belirleme yollarıyla ilgili olarak ayrıca bk. Gökçe, İbn Ebî Hayseme'de Sahabe Bilgisi, s. 17-19.

127 İbn Ebî Hayseme, Târîh, I, 139 (prg. 283).

128 İbn Ebî Hayseme’nin konuyu Târîh'inde incelemesinden önce İbnü’l-Medînînin yanı sıra Müslim b. el-Haccâc da kardeş râvilere dair bir kitap yazmış, İbn Ebî Hayseme’nin çağdaşı olan Ebû Davud da bu alanda müstakil bir eser kaleme almıştır. Ancak İbn Ebî Hayseme’nin son ikisinden haberdar olduğuna veya etkilendiğine dair bir işaret yoktur. Ebû Davud, İbnü’l-Medînînin kitabını oğlu vasıtasıyla edinip okumuş, ayrıca Ahmed b. Hanbel ve Muśab b. Abdullah ez-Zübeyri'den aldığı bilgileri eserine ilave etmiştir. Çağdaş araştırmacılardan Bâsim Faysal, İbnü’lMedînînin kitabıyla Ebû Davud'un çalışmasını birlikte neşretmiş, bu ikisinde yer almayan kardeş râvileri de kitabın sonunda müstakil bir bölümde derlemiştir (Ali b. el-Medînî-Ebû Davud es-Sicistânî, er-Ruvât mine'l-ihve ve'lahavât). Ebû Davud'un eseri hakkındaki bilgi için bk. a.g.e., s. 162. 
aynen mevcuttur. ${ }^{129}$ Ancak yukarıdaki örneklerde belirtildiği gibi yazarın başka kişilerden nakillerle veya kendisine ait isnadlarla kardeşliği tespit ettiği yerler de bulunmaktadır. ${ }^{130}$

İbn Ebî Hayseme’nin "márifetü'l-ihve" konusuna gösterdiği ilginin, döneminde tarihçilik ve hadisçilik nosyonlarına beraberce sahip olan başka kimselerce de paylaşıldığı anlaşılmaktadır. Sözgelimi, onunla aynı dönemde benzer çalışmalar yapmış olan Fesevî (ö. 277/890) de Márife'sinin muhtelif yerlerinde kardeş râvilere dair kayıtlar düşmüştür. ${ }^{131}$ Sonuç olarak İbn Ebî Hayseme ve Fesevî gibi isimlerin çalışmaları, râvilerin kardeşlik bağlarını tespit için erken dönemde yazılmış olan İbnü’l-Medînînin ve Ebû Davud’un eserleri gibi başlıca kaynaklar arasında sayılmalıdır.

\section{Sonuç}

Râvi tenkidi bir şahsın adalet ve zabt durumunu inceleyip hakkında genel bir hüküm belirtmek şeklinde tanımlanırsa, İbn Ebî Hayseme’nin önde gelen bir münekkit olarak nitelenmesi doğru olmayacaktır. Zira o, sayılı istisnalar dışında râviler hakkında bağımsız bir değerlendirme yapmamış, ağırlıklı olarak Yahya b. Maîn’in görüşlerini nakletmiştir. Bununla birlikte o, râvi araştırmasının ayrılmaz unsurları olan soy ve tabaka, vefat tarihleri, hoca-talebe ilişkileri ve dolayısıyla hadislerin ittisal-inkıtâ durumları gibi konulardaki bilgisiyle temâyüz etmiş, hadis rivayetleri arasındaki farklılıklara da zaman zaman işaret etmiştir. İbn Ebî Hayseme’nin tarihçilik nosyonu ve kısmen ilel farkındalığ 1 gerektiren bu türden bilgilere sahip olması, cerh-tádîle dair müstakil hüküm pek belirtmemesine rağmen tenkitçi nazardan uzak kalmadığını göstermektedir.

Hiç şüphesiz İbn Ebî Hayseme, râvileri ve naklettikleri metinleri mukayeseli biçimde inceleyerek rivayetlerin shhat durumunu belirlemek anlamına gelen hadis tenkidiyle üst seviyelerde meşgul bir çevre içinde yetişmiştir. Buna rağmen onun münekkit yönünü tebârüz ettirmede yaşadığımız zorluk, II-III./VIII-IX. yüzyıllarda hadis tenkidinin gerçekleştirildiği bu çevreleri ve onların çalışma tarzını hâlen yeterince bilmiyor oluşumuzdan, buna bağlı olarak "münekkit tipoloji”lerine sahip olmamamızdan kaynaklanmaktadır. Meselâ münekkit kimliği ortada olan Yahya b. Maîn gibi birine talebe olmanın anlamı nedir? Talebelerin onun temsil ettiği tenkit anlayışı ve düzeyine katılımları ne ölçüdedir? Cerhta‘dîl müzâkereleri nasıl işler, hangi metotlar kullanılır, nasıl kayıt tutulur? Yapılan işlerin yalnızca hadislerin nakledildiği rivayet halkalarından farklı olan yönleri nelerdir? Bu gibi

129 Krș. İbn Ebî Hayseme, Târîh, I, 94 (prg. 41 vd.); Ali b. el-Medînî-Ebû Davud, er-Ruvât mine'l-ihve ve’l-ahavât, s. 73 (prg. 384 vd.). İbn Ebî Hayseme’nin, yukarıda belirtildiği üzere, Ali b. el-Medînînin kitabını doğrudan kendisinden değil vasıtalı olarak edinmesi, "بلغني" lafzını kullanmasının sebeplerinden biri olabilir.

${ }^{130}$ Meselâ babasının kitabından aldığını belirttiği bir örnek için bk. İbn Ebî Hayseme, Târîh, I, 121 (prg. 153). Başka bazı kaynak isimler için bk. Târîh, I, 101-102 (prg. 70, 72, 73).

131 bk. Âşıkutlu, Fesevî ve Ricâl İlmindeki Yeri, s. 101-104. 
sorular cevaplanmadıkça İbn Ebî Hayseme veya bir başkası hakkında yapılacak değerlendirmeler mevziî kalacaktır.

Ülkemizde İslâm tarih yazıcılığının erken dönem eserlerinin her nedense uzun süre ihmal edilmiş olması, Hadis-Tarih ilişkisinin nitelikli biçimde ele alınamamasının, dolayısıyla İbn Ebî Hayseme’nin Târîh'i gibi kitapların ilmî-edebî bir bağlam içinde incelenememesinin başlıca sebebidir. Bir kısmı bu makalede zikredilen muhaddis-ahbârî şahsiyetler hakkında yapılacak çalışmalar Hadis'in Tarih'le kesişen yönlerini ortaya koyacağı gibi İslâm tarihçiliğinin kendi gelişimine de 1şık tutacaktır.

İbn Ebî Hayseme’nin Târîh'i günümüzde bütünüyle mevcut olmasa da, diğer kaynakların İbn Ebî Hayseme’den yaptığı nakillerden hareketle eseri kısmen inşâ etmek mümkün gözükmektedir. Müstakil bir metodolojisi ve çalışma esasları bulunan "kaynak inşâ" faaliyeti, Târîh çerçevesinde ilgililerini beklemektedir.

Tehzîbü't-Tehzîb'de İbn Ebî Hayseme’ye yapılan yoğun atıfların peşine düşerek başlanan bu çalışmanın, yukarıda dile getirilen tekliflerin gerçekleştirilmesi yolunda küçük bir katkı olması ümit edilmektedir. 


\section{Kaynaklar}

Ahatl, Erdinç, Yahya b. Maîn ve Cerh-Tádildeki Metodu (yüksek lisans tezi, 1992), Bursa Uludağ Üniversitesi SBE.

Ali b. el-Medînî-Ebû Davud es-Sicistânî, er-Ruvât mine'l-ihve ve'l-ahavât (nşr. Bâsim Faysal el-Cevâbire), Riyad: Dâru’r-Râye, 1408/1988.

Arnaût-Ma'rûf: Şuayb el-Arnaût-Beşşâr Avvâd Márûf, Tahrîru Takrî̉i’t-Tehzîb, I-IV, Beyrut: Müessesetü’rRisâle, 1417/1997.

Âşıkkutlu, Emin, Fesevî ve Ricâl İlmindeki Yeri, İstanbul: İFAV, 2007.

Aydınl, Abdullah, "İbn Ebû Hayseme”, DİA, XIX, 434.

el-Bâcî, Ebü’l-Velîd Süleyman b. Halef, Kitâbü't-Ta'dîl ve't-tecrîh li-men harrece lehü'l-Buhârî fi'l-Câmii'ssahîh (nşr. Tahir Salih Hüseyin), I-III, Tunus: Dâru'l-Garbi'l-İslâmî, 1431/2010, 2. Bask1.

el-Bağdâdî, Hatîb, Ebû Bekir Ahmed b. Ali, Târîhu medînetis'selâm (nşr. Beşşâr Avvâd Ma'rûf), I-XVII, Beyrut: Dâru'l-Garbi'l-İslâmî, 1422/2001.

ed-Dûrî, Abdülazîz, Neş'etü ilmi't-tarih inde'l-Arab, Beyrut: Merkezü Dirâsâti'l-Vahdeti'l-Arabiyye, $1428 / 2007,2$. Bask1.

Fayda, Mustafa, “İbn Sad”, DİA, XX, 294-297.

Gökçe, Aziz, İbn Ebî Hayseme’de Sahabe Bilgisi (yüksek lisans tezi, 2011), Sakarya Üniversitesi SBE.

Görmez, Mehmet, "Kâsım b. Asbağ", DİA, XXIV, 540-541.

Halîfe b. Hayyât, Ebû Amr el-Basrî, Kitâbü’t-Tabakât (nşr. Süheyl Zekkâr), I-II, Dımaşk: Vizâretü’s-Sekâfe ve's-Siyâha, 1966.

el-Halîlî, Ebû Ya'lâ Halîl b. Abdullah, Kitâbü'l-İrşâd fî ma'rifeti ulemâi'l-hadîs (nşr. Muhammed Saîd b. Ömer İdris), I-III, Riyad: Mektebetü’r-Rüşd, 1409/1989.

Işık, Mustafa, Yahya bin Mâ̂n’in Hayatı ve Hadis İlmindeki Yeri (yüksek lisans tezi, 1991), Erciyes Üniversitesi SBE.

İbn Adî, Ebû Ahmed Abdullah b. Adî el-Cürcânî, el-Kâmil fî duafâi'r-ricâl (nşr. Mâzin es-Sirsâvî), I-X, Riyad: Mektebetürr-Rüş, 1434/2013.

İbn Asâkir, Ebü'l-Kâsım Ali b. el-Hasan, Târîhu medîneti Dımaşk (nşr. Ömer b. Garâme), I-LXXX, Beyrut: Dâru'l-Fikr, 1415/1995.

İbn Ebî Hâtim, Ebû Muhammed Abdurrahman b. Ebû Hâtim er-Râzî, Kitâbü’l-Cerh ve't-ta'dîl, I-IX, Haydarabad: Dâiretü'l-Maârifi'l-Osmâniyye'den ofset, 1371/1952.

İbn Ebî Hayseme, Ebû Bekir Ahmed b. Züheyr b. Harb, et-Târîhu'l-kebîr: Târîhu İbn Ebî Hayseme (nşr. Salâh b. Fethî Helel), I-IV, Kahire: el-Fârûku'l-Hadîse, 1429/2008, 2. Bask1.

-----, Târîhu İbn Ebî Hayseme: Kit'atün mine’l-kûfiyyîn (nşr. Muhammed b. Abdullah es-Süreyyi'), Riyad: Dâru'l-Âsıme, 1435/2014.

İbn Ebî Ya'lâ, Ebü'l-Hüseyin Muhammed el-Ferrâ, Tabakâtü'l-Hanâbile (nşr. Abdurrahman b. Süleyman elUseymîn), I-III, Riyad: el-Emânetü'l-Âmme li'l-İhtifâl, 1419/1999.

İbn Hacer, Ahmed b. Ali b. Hacer el-Askalânî, Lisânü'l-Mîzân (nşr. Abdülfettah Ebû Gudde), I-X, Beyrut: Mektebü'l-Matbûâti'l-İslâmiyye, 1423/2002.

------, Tehzîbü't-Tehzîb (nşr. İbrahim Zeybek-Âdil Mürşid), I-IV, Beyrut: Müessesetürr-Risâle, 1432/2011.

İbn Hayr el-İşbîlî, Ebû Bekir Muhammed b. Hayr, Fihristü İbn Hayr el-İşbîlî (nşr. Beşşâr Avvâd MárûfMahmud Beşşâr Avvâd), Tunus: Dâru'l-Garbi'l-İslâmî, 1430/2009.

İbn Hibbân, Ebû Hâtim Muhammed b. Hibbân el-Büstî, Kitâbü'l-Mecrûhîn mine'l-muhaddisîn (nşr. Hamdî Abdülmecîd es-Selefî), I-II, Riyad: Dâru's-Sumay'î, 1428/2007. 
İbnü'l-Ebbâr, Ebû Abdullah Muhammed b. Abdullah, el-Mu'cem fî-ashâbi'l-Kâdî es-Sadefî Ebî Ali el-Hüseyin b. Muhammed (nşr. İbrahim el-Ebyârî), Beyrut: Dâru’l-Kitâbi'l-Lübnânî, 1410/1989.

İbnü’n-Nedîm, Ebü'l-Ferec Muhammed b. İshak, el-Fihrist, Beyrut: Dâru’l-Márife, 1398/1978.

İbnü's-Salâh, Ebû Amr Osman b. Abdurrahman eş-Şehrezûrî, Ulûmü’l-hadîs (nşr. Nureddin Itr), Dımaşk: Dâru'l-Fikr, 1423/2002, 3. bask1.

Kallek, Cengiz, "Medâinî”, DİA, XXVIII, 291-292.

Karagözoğlu, Mustafa Macit, Zayıf Râvîler: Duafâ Literatürü ve Zayıf Rivayetler, İstanbul: İFAV, 2014.

Khalidi, Tarif, Arabic Historical Thought in the Classical Period, New York: Cambridge Univ. Press, 1994.

el-Mizzî, Ebü'l-Haccâc Cemaleddin Yusuf b. Abdurrahman, Tehzîbü’l-Kemâl fî̀ esmâi’r-ricâl (nşr. Beşşâr Avvâd Marrûf), I-XXXV, Beyrut: Müessesetü’r-Risâle, 1403/1983, 2. Bask1.

Önkal, Ahmet, "Araplarda Ensâb İlmi ve İslâm Tarihi Açısından Önemi”, Selçuk Üniversitesi İlâhiyat Fakültesi Dergisi, 1990, sy. 3, s. 117-132.

Özşenel, Mehmet, "Bir Kemâlin Hikâyesi: el-Makdisînin el-Kemâl fî esmâiir-ricâl'inin Dört Asırlık Serüveni”, Dîvân, 2001, XI, sy. 2, s. 155-161.

Robinson, Chase F., Islamic Historiography, New York: Cambridge Univ. Press, 2003.

Rosenthal, Franz, A History of Muslim Historiography, Leiden: Brill, 1968, 2. bask1.

es-Sehâvî, Muhammed b. Abdurrahman, "el-Mütekellimûn fi'r-ricâl", Erba'u resâil fî-ulûmi'l-hadis (nşr. Abdülfettah Ebû Gudde), Beyrut: Dâru'l-Beşâiri'l-İslâmiyye, 1428/2007, 6. bask1.

Sezgin, Ursula, "Al-Madāinī”, $E I^{2}, \mathrm{~V}$, 946-8.

es-Süreyyi', Muhammed b. Abdullah, el-Ehâdîs elletî zekera İbn Ebî Hayseme fîhâ ihtilâfen fî̀ et-Târîhi'l-kebîr (yüksek lisans tezi, 2014), Kasîm (Suudi Arabistan).

-----, http://www.alukah.net/sharia/0/104544/ (Erişim Tarihi: 24.02.2017).

es-Süyûtî, Celaleddin Abdurrahman b. Ebû Bekir, Tedrîbürr-râvi fî şerhi Takrîbin'n-Nevevî (nşr. Muhammed Avvâme), I-V, Medine: Dâru'l-Yüsr, 1437/2016.

Tatlı, Mustafa, Rical Bilgisinin Tespiti: Suâlât Literatürü, İstanbul: Beka Yayıncılık, 2016.

Tuğ, Salih, Hadis Edebiyatında Gelişim Safhaları ve Ebû Hayseme Zuheyr'ubn Harb’in (160-234 H / 776-849 M) "Kitâbüll-İlm”inin Bu Gelişmedeki Yeri ve Önemi (Profesörlük Takdim Tezi, 1977), İstanbul.

Turhan, Halil İbrahim, Ricâl Tenkidinin Doğuşu ve Gelişimi: Hicrî İlk İki Asır, İstanbul: İFAV, 2015.

Uyar, Gülgün, “Abbâsî Coğrafyasında Bir Neseb Âlimi: Zübeyrî (236/851) ve Kitâbü Nesebi Kureyş’ine Göre Neseb Bilimi Usul, Muhteva ve İfade Şekilleri”, İstem, 2008, VI, sy. 12, s. 127-152.

Vekî́, Muhammed b. Halef b. Hayyân, Ahbâru'l-kudât, Beyrut: Âlemü’l-Kütüb, 1432/2011.

el-Vüseynî, Senâ, "İbn Ebî Hayseme ve Kitâbühû et-Târîh: Min hilâli nüsha hattıye 'atîka”, Mecelletü Dâri'lHadîsi'l-Haseniyye, 1999, sy. 16, s. 391-457.

Yahya b. Maîn, Yahya b. Maîn ve Kitâbühû et-Târîh (nşr. Ahmed Muhammed Nur Seyf), I-IV, Mekke: Merkezü'l-Bahsi'l-İlmî ve İhyâi't-Türâsi'l-İslâmî, 1399/1979.

------, Mevsûatü akvâli Yahya b. Maîn fî ricâli’-hadîs ve ilelih (nşr. Beşşâr Avvâd Ma'rûf-v.dğr.), I-V, Tunus: Dâru'l-Garbi'l-İslâmî, 1430/2009.

------, Mevsûatü Târîhi İbn Maîn: Hamsü rivâyet (nşr. Muhammed Osman), I-II, Beyrut: Dâru'l-Kütübi'lİlmiyye, 1432/2011.

Yazıcı, Mahmut, Sahâbe Bilgisinin Tespiti, İstanbul: İFAV, 2015.

ez-Zehebî, Şemseddin Muhammed b. Ahmed b. Osman, el-Kâşiffî márifeti men lehû rivâye fi'l-Kütübi’s-sitte (nşr. Muhammed Avvâme-Ahmed Muhammed Nemr Hatîb), I-V, Medine: Dâru'l-Yüsr, 1430/2009, 2. bask1. 
------, Mîzânü̉l-i'tidâl fî-nakdirr-ricâl (nşr. Ali Muhammed Muavvaz-Adil Ahmed Abdülmevcûd), I-VII, Beyrut: Dâru'l-Kütübi'l-İlmiyye, 1416/1995.

------, el-Muğnî fi'd-duafâ (nşr. Nureddin Itr), I-II, Haleb: Dâru'l-Maârif, 1391/1971.

------, Siyeru a'lâmi’n-nübelâ (nşr. Şuayb el-Arnaût-v.dğr.), I-XXVIII, Beyrut: Müessesetü’r-Risâle, 1429/2008, 2. bask1.

------, “Zikru men yu'temed kavlühû fi'l-cerh ve’t-ta‘dîl”, Erba'u resâil fî-ulûmi'l-hadis (nşr. Abdülfettah Ebû Gudde), Beyrut: Dâru'l-Beşâiri'l-İslâmiyye, 1428/2007, 7. Baskı.

ez-Zübeyrî, Ebû Abdullah Muśab b. Abdullah, Kitâbü Nesebi Kureyş (nşr. E. Levi Provençal), Kahire: Dâru’lMaârif, 1402/1982, 3. bask1. 